\title{
Urban Geography
}

\section{The risky business of real estate developers: network building and risk mitigation in London and Johannesburg

\author{
--Manuscript Draft--
}

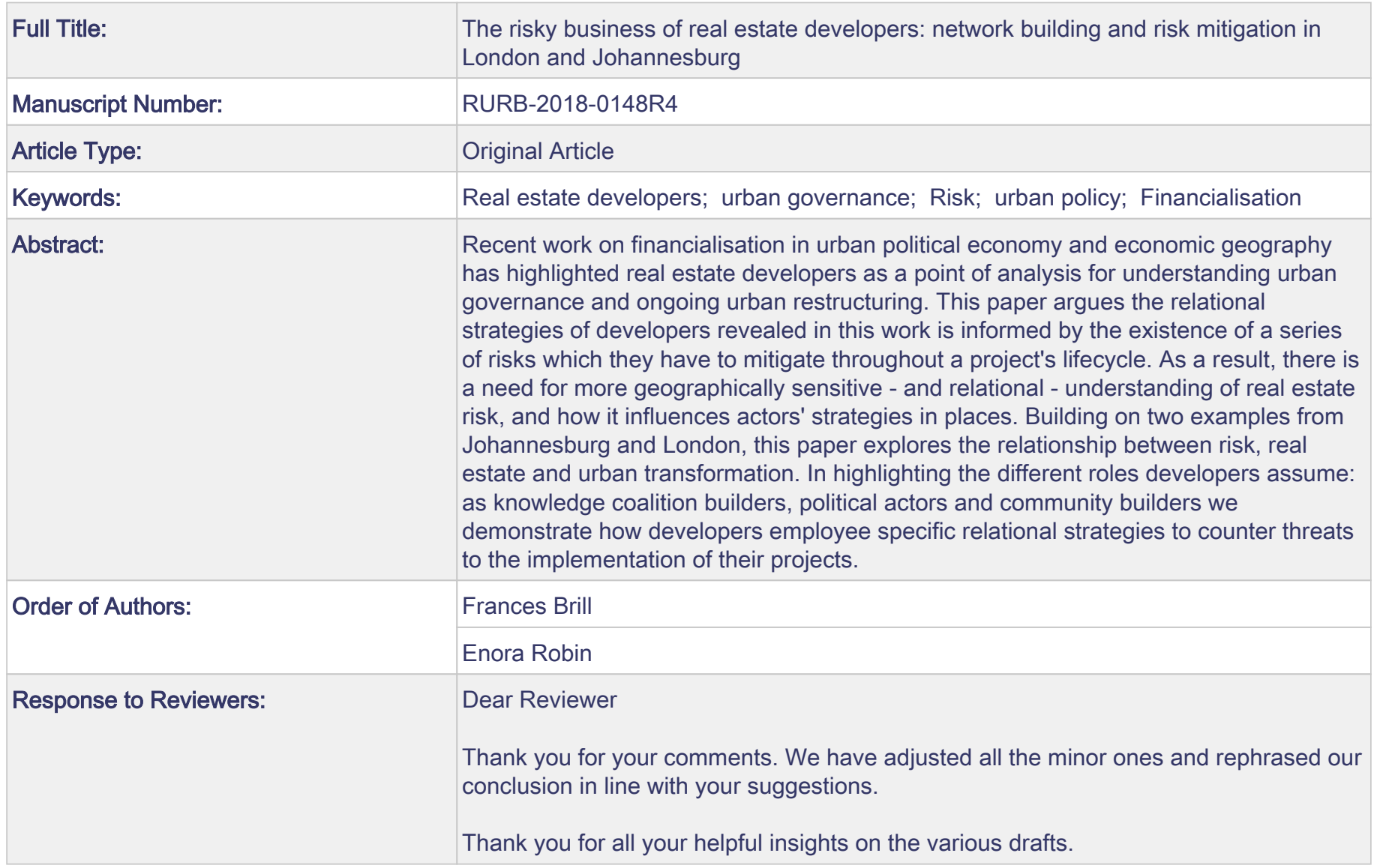


The risky business of real estate developers: network building and risk mitigation in London and Johannesburg.

\begin{abstract}
Recent work on financialization in urban political economy and economic geography has highlighted real estate developers as a point of analysis for understanding urban governance and ongoing urban restructuring. This paper contributes to this literature by showing how an analytical entry point focused on risks mitigation can help better understand the position of developers in urban governance. In doing so, we call for more geographically sensitive understanding of real estate risk and its influence on developers' strategies in specific places. Building on two examples from Johannesburg and London, this paper highlights the different roles developers assume as knowledge coalition builders, political actors and community builders, to counter threats to the implementation of their projects.
\end{abstract}

\title{
Keywords:
}

real estate developers - urban governance - risk - urban policy 


\section{Introduction}

"If money was no object, any builder would come and build low cost housing but obviously developers are in it for the money - they want money" (JBG_engineer, 2017)

In the aftermath of the 2008 financial crisis, an increasing body of work in critical urban research has explored the ways through which urban development has become financialized (Aalbers, 2018, Aalbers, 2015, Guironnet and Halbert, 2014, Haila, 2016, Halbert and Attuyer, 2016, Peck and Whiteside, 2016, Pike and Pollard, 2010, Rutland, 2010, Weber, 2010). Authors have argued that the increased involvement of global finance in urban developments has been made possible by the development of legal and institutional frameworks that stimulate private sector investments in, and management of, the built environment (Fields, 2018, Weber, 2015, Gotham, 2006, 2009). This has contributed to increasing local governments' reliance on private-led developments to fund core activities (Beswick and Penny, 2018, Robin, 2018, Penny, 2017, Weber, 2002, 2010), for instance through land value capture (Smith, 2002), resulting in growing spatial inequalities and homogenized urban forms (Guironnet and Halbert, 2014). Scholarship has highlighted the key role of intermediaries including brokers, consultants and property developers in anchoring financial capital in particular places (Theurillat et al., 2016) through the transformation of the urban built form and cities' institutional fabric (Brill, 2018; Fernandez et al., 2016, Searle, 2014, Halbert and Rouanet, 2014, David, 2012). Within this literature, real estate developers have been the focus of an increasingly large body of work that shows their role in attracting investments to particular places and their active involvement in urban decision-making (cf. Brill, 2018, Robin, 2018, Geva and Rosen, 2018, Ward and Swyngedouw, 2018, Guironnet et al., 2016, Halbert and Rouanet, 2014, Theurillat and Crevoisier, 2013, Shatkin, 2008, Fainstein, 2001). Within developers' actions to channel mobile capital flows into particular locations, the management and mitigation of a series of investment risks has been shown to influence what gets built and where (Halbert and Rouanet, 2014) as investment choices are themselves shaped by investors' perceptions of a series of risks attached to particular locations (Fields and Uffers, 2016, David, 2012). In other words, as shown by Halbert and Rouanet (2014) the financialisation of urban development requires the constitution and maintenance of trans-scalar territorial networks to support the process of 'filtering risk away' and fixing investments in particular place.

This paper hopes to further build on and advance these discussions, exploring how developers navigate the risks associated with 'landing' in particular places, to bring forth a more nuanced understanding of the process through which these actors shape contemporary urban governance and urban development trajectories. In doing so, we explore the territorial implications of developers' risk mitigation strategies, asking: how can a focus on developers' risk management strategies help elucidate a deeper understanding of the geographical implications of financialization? To address these issues, the next section reviews existing work on developers' activities and argues that these can be better understood through the lens of 'risk' and the imperative of risk mitigation. Drawing on this argument and through

a social constructivist understanding of risk we introduce a framework for analyzing developers that is attendant to risk beyond pure 'financial' or investments risks (although we address those), which integrates the importance of localized regulatory and political risks (Searle, 2014, Halbert and Rouanet, 2014). We then illustrate the value of this approach in the study of two large scale urban development projects in Johannesburg and London, highlighting the specific roles developers assume in those cases to mitigate various risks attached to their projects. The last section concludes and discusses further research avenues.

\section{Understanding the work of real estate developers and the role of risk}

Real estate development encompasses a wide range of decisions spread across time and space (cf. Ball, 2006, Graaskamp, 1981), each requiring real estate actors - and developers in particular - to engage 
with global stakeholders and local actors, to differing degrees. This relational work is well understood in the context of developers' political work (Brill, 2018, Hyde, 2018, Weber, 2015, Weinstein, 2014, Shatkin, 2008, Fainstein, 2001) and their ability to shape the legal and broader institutional settings in which they must work (Leffers, 2017). This is especially true in the early stages of the development process when developers seek to secure planning permission, often directly negotiating with public authorities, at the sub city, city or national level (Weber, 2010; Guironnet et al., 2016, Teresa, 2017). This capacity to navigate complex institutional settings reinforces their position in city building (Leffers, 2017, Mosselson 2017, Coiacetto, 2001, Fainstein, 2001), sometimes to the point of challenging the capacity of local government themselves in determining the shape, trajectory and location of urban developments (Robin, 2018, Theurillat et al., 2016, Guironnet et al., 2016).

The importance of this relational work directs our attention to the kinds of relationships developers have to forge to navigate risks and uncertainties throughout their projects' lifecycle (Chen and Khumpaisal, 2009), for example navigating the tensions of market rationalities (Rivero et al., 2017). In particular, we see how in addition to relationship building with communities and the public sector (Geva and Rosen, 2018, Weiss, 1987), the pre-planning permission stage of a project is also shaped by developers' interactions with investors. This role has been illuminated and analyzed extensively by recent urban political economy research on financialization. This body of work has revealed how, in some cases, the interactions between developers and investors shape what is built and where (Coiacetto and Bryant, 2014) as developers work to make land "fit for investment" (Sanfelici and Halbert, 2016, Searle, 2014, Halbert and Rouanet, 2014). Moreover, as this process is increasingly understood, the importance of interactions with other actors has been revealed to show how real estate is influenced by the work of experts, market analysts and brokers working for investors (Crosby and Henneberry, 2016, Akers, 2015, Searle, 2014, David, 2012, Fainstein, 2001). These actors shape developers' behavior by translating investors' requirements into elements of the project. For instance, highlighting expected rates of returns on investments which then heavily influences both investment location and the content of real estate projects (Crosby and Henneberry, 2016, Halbert and Rouanet, 2014, David and Halbert, 2014).

In a context characterized by the increasing internationalization and financial integration of the real estate industry, global investors bring with them alternative conceptualisations of risk, or what David (2012) and Corpataux et al (2009) note are 'new perceptions' of risk (for a discussion of the political economy of different perceptions of risk see Gotham, 2016). As such, of particular importance in financialised settings and locations where investors are from abroad, is the developer's role in helping shape and mitigate potential risks (cf. Geva and Rosen, 2018, Rosen 2017, David, 2012,). Responding to this, recent literature has shown how developers shape the way investors experience the risk of investing in particular cities or projects. Seminal in this work is David's (2012) study of Mexico City. Through her institutionalist analysis she demonstrates the territorialised nature of financial flows in real estate. Specifically, by analyzing how a relatively 'new' market for international investors shifted over time from being 'took risky' to manageable, David (2012) highlights how developers shape investors' perceptions of the risks attached to investing in particular locations. In doing so she encourages analysis to look at non-financial actors (for example, developers) who work to transform markets. David's (2012) analysis directly speaks to Halbert and Rouanet's (2014) work on Bangalore. They show, in their words, how local and regional real estate actors, including developers, 'filter away' the risks of real estate in Bangalore. These actors make land legible to international investors and through this mediate expectations (see also Guironnet et al., 2016 for a discussion of these issues in the Paris region). The authors show how land assembly practices and the standardisation of data for international investors contribute to this process of filtering risk away. These two case studies are vital in understanding development risk, as their authors demonstrate how developers internalize investors' definitions of risks into their strategies on the ground and at different scales of governance (from the local to the global). 
In our work, we draw on both David (2012) and Halbert and Rouanet (2014) to elucidate how real estate professionals manage 'risk'. However, we depart from their approaches by moving beyond a focus on financial risks related to expected returns for investors to integrate other dimensions of risks, as perceived and experienced by developers themselves. As Halbert and Rouanet explain their work is concerned with how "from an investor perspective, the real estate industry absorbs a series of risks associated with the local-regional institutional workings that characterize land and business property development markets" (2104: 479). In this paper we respond to this, continuing an analysis of the series of risk but from a developer's perspective that highlights the localized production of risk. We therefore look at how market and development risks emerge in particular places, which in turn shape how risks manifest and influence developers' strategies. In this endeavour we draw on David's social constructivist understanding of risk which demonstrates "the need to develop approaches that consider that economic practices embody economic, social, political and cultural logics at the same time" (2012: 35), practices which in turn are embedded in particular places. This calls for a better conceptualization of the work risk does and how it shapes developers actions in different locations. In particular, it requires us to explore how risk is understood and perceived by developers themselves as these land in particular places, and how their territorialized relational strategies are guided by such perceptions.

Risk is both a relatively predictable dimension of a real estate project, and a relatively subjective notion grounded in individual experiences and perceptions. In technical and economic studies, risk is portrayed as a predictable dimension of project management, commonly accepted as the variation from expected outcome, where expected outcome is based on past experiences' average (Kallman, 2005). Following this, in practice, analysts typically apply this definition of risk to a project through ratios which compare projects to alternatives and measure the relative deviance between different scenari. This classical narrative dominates financial, project management and neoclassical economics studies of risk, which are widely used in the real estate industry and portfolio management. Building on this, as is revealed through recent political economy analysis, portfolio management, through risk diversification, has become a core component of value generation in financialised societies (Ascher, 2016, David, 2012, Corpotaux et al., 2009). In the context of real estate, existing research from project management studies highlights key dimensions of supposed objective risk including financial risks, physical risks and regulatory risks (Huffman, 2003). Additionally, Chan et al., (2005) also argue environmental and social risks are likely to affect a project's expected returns on investments.

Political and regulatory challenges are further explored in Kimelberg's (2011) assessment of the challenges developers face. Her work highlights the following potential risks: the importance of re-election for local politicians, the interest of local municipality staff, zoning regulations; and orchestrated community push-backs (ibid.). Experts work hand in hand with real estate developers to identify such risks, to anticipate their likelihood, to assess their impact on real estate markets behaviour and project viability, and to develop mitigation strategies, for instance through the production of "risk matrices" and "financial viability assessments" (Robin, 2018, Henneberry and Crosby, 2016, French and Gabrielli, 2006) The employment of such techniques in turn influences the location and geography of investment in real estate, as well as the type of projects that eventually gets built - e.g. mixed-use schemes evident globally (Guironnet and Halbert, 2014). However, real estate projects and the risks they entail are not purely (if at all) the product of rational decisions or events that can be modelled and predicted, because they are embedded in the messy socio-economic and cultural context of their location. As such, research has shown that understandings of risks resting on quantification - and the meaning associated with probabilistic metrics - is mediated by interpretative work that is socially and spatially grounded (see Zaloom, 2003 for a discussion of "ambiguous numbers" and decision making on financial markets, David, 2012). Real estate developers therefore know that every project carries "uncertainties and risks that cannot be predicted", especially in long-term large scale redevelopment projects (LDN_Developer, 2016). 
Following on from this, risk itself, whilst a relatively objective calculation for some real estate professionals, must be acknowledged as something which is not experienced homogeneously (Brown and Young 2011). Investors and developers' appreciation of risk is subject to individual bias where the identification, definition, evaluation, perception of and reaction to risks is context-specific. Such differentiated experiences of risk emphasize environmental factors and in turn influence decision-making in uncertain situations (cf. Douglas and Wildavsky, 1982). Social constructivist analysis has shown risk to be embedded in specific socio-cultural contexts, highlighting that understandings of risks, and risks themselves, are socially constructed, negotiated, contested, reconfigured and mediated, notably through the work of experts (David, 2012), but not only (Blok, 2016). In that sense, "there is a continual definitional struggle over risk [...] as a result, risk has become a highly politicized concept" (Lupton, 1999, 68). Mairal offers a particularly insightful way of engaging with risk in comparative and relational studies of real estate: recognising the relational nature of development, he sees risk as "a frame that creates contexts which bring together an 'object of risk' (a hazard or source of potential harm), an 'object at risk' (a target of potential harm) and an evaluation (implicit or explicit) of human consequences" (2008, p. 42). This leads us to argue that real estate developers, when they land in particular places, engage in relational work to identify objects of risks (attached to the local context) and to gain knowledge about the likelihood and impacts of those on their projects (the object at risk). Risks definition, anticipation and mitigation can be seen, in that sense, as relational and geographically embedded.

We take this proposition forward in what follows, mobilizing risk as an analytical entry point to understand real estate developers' behavior. This, we argue, enables a deeper understanding of the territorialized nature of real estate development processes. The next sections exemplify the value of this approach through the study of private developers ${ }^{1}$ activities in two large-scale redevelopment projects in London and Johannesburg. Our comparison focuses on developers' strategies in relation to three specific categories of risks (1) those related to the local market, (2) the political environment and (3) the strength of local communities. In direct response to these, our research finds developers enact different roles in local governance settings, that of (a) coordinators of knowledge in and about particular locations; (b) political actors; (c) and community builders.

\section{Introducing our cases: Modderfontein, Johannesburg and Kings Cross, London}

This paper generates insights on developers' role in local governance by looking at how they identify and navigate different risks in two large scale redevelopments: Modderfontein in Johannesburg and King's Cross Central London. We explore these issues within a specific timeframe: the pre-planning phase of both redevelopment projects. The findings presented in this paper result from ongoing collaboration between the two authors, and highlight the value of speaking across two cities, especially two sites which at first sight might seem to have little in common. However, Modderfontein and King's Cross Central are both historically significant areas: the King's Cross Railway Lands were a core site of industrial London and Modderfontein is home to an explosives factory which enabled Johannesburg's mining industry. Arguably, given the strategic importance of London as a base for Britain's global trade and Johannesburg as a mining city, without these sites neither city would have the global position they occupy today. Their shared strategic significance is something local authorities were keen to take advantage of and, as such, both mega-projects received extensive attention from governments (local and national), investors and the media.

\footnotetext{
${ }^{1}$ We contend that the developers leading such projects are not representative of all developers - given the large variety in types of developers shaping urban transformations - but they nonetheless represent a relevant entry point to understand how international financial capital gets channeled into the built environment and shapes contemporary urban trajectories.
} 
Modderfontein is the largest plot of land left in the great Johannesburg region and was purchased in 2012 from a local developer, Heartland, by Zendai, a Shanghai developer who wanted to build a new piece of city. Zendai's involvement in South African real estate was motivated by a desire to divest from the Chinese market and seize the opportunities offered elsewhere: it was an entirely new type and location of venture for them. Unlike many developers in the Global South, Zendai were not tied to political actors or the state itself (Shatkin, 2014), oligarchs (Winarso and Firman, 2002) or from financially important families in the city (Garrido, 2013), and this lack of connections is vital in understanding how the process unfolded in terms of their capacity to leverage material and political connections to cultivate land for development. Zendai's proposal was announced by provincial government, Gauteng Province, and at the same time local media outlets spread the news of a 87billion ZAR investment fund. In the face of this political buzz, Zendai wanted to capitalize on the opportunity to engage with an international team so in 2015 a 'global' team, primarily from London, were hired to produce a masterplan. Findings from this case are based on 48 interviews with people who worked for Zendai between 2012 and 2016 in their planning department, environmental team and finance department, as well as the development lead; their consultant team in London and Johannesburg; employees of the City of Johannesburg's (CoJ) planning department; and Gauteng officials. These interviews focused on the Zendai's strategies: their objectives, how these evolved over the course of their project, their everyday actions, who and how they interacted with different people in the planning application process and what information they used to inform their perspectives. These interviews were read alongside Johannesburg's Spatial Development Framework; internal commercial reporting; interim masterplan feedback between $\mathrm{CoJ}$ and Zendai, and the eventual masterplan.

King's Cross Central is one of the largest redevelopments in Central London. Since the 1980s, the site was on the radar of national and local government, regarded as a prime opportunity for new office space in the crowded British capital, and for increasing housing provision (Parkes, 2000; London Borough of Camden, 2004). After attempted development in the 1990s, pre-crash of the property market, the early 2000s were marked by the appointment of Argent as a developer for the site. The masterplan for the site was approved in 2006 and construction work started in 2007. The scheme has been the subject of numerous academic inquiries, exposing its conflictual nature (Papin and Newman, 2010), and notably investigating how, because of its inherently commercial nature, it failed in integrating the needs of local communities (Edwards, 1992, 2009; Parkes, 2000; Holgersen and Haarstad, 2009; Campkin, 2013). The study focuses on the 2000-2006 period during which the planning application for the main area of the King's Cross site was developed, revised and approved. The findings proceed from interviews $(n=18)$ with key informants involved in the planning process (developers, architects, consultants, politicians, community groups and local authorities at the Borough and Metropolitan level) and from the analysis of all planning documents and supporting evidence produced between 2000 and 2006 by the developer and the consultants it hired; minutes from 26 meetings from the King's Cross Development Forum (umbrella organization for local community groups) between 2002 and 2006 which capture some of the key controversies that emerged in the masterplanning process, including communities' concerns vis-à-vis the developer strategy; and of news articles and consultation documents (e.g. community responses to the different versions of the masterplan submitted by the developer). The interviews focused on exploring the importance of the knowledge production process in mitigating development risks, the developer (and its team) relationship vis-à-vis public, private and community stakeholders and how different actors perceived re-development risks. The document and minutes review explored how redevelopment risks were framed, known and acted upon, and which challenges emerged for the developer in the formulation of risk-mitigation strategies. 


\section{Risk mitigation in action: tracing developers' networks in Johannesburg and London}

\section{Developers as knowledge-coalition builders}

When beginning a project developers need to source knowledge from an extensive web of consultants to investigate the sites' specificities and economic opportunities, as well as the legal and political context. Building on existing research highlighting the power of consultancies in urban decision-making (Fainstein, 2001), our research highlights how generating knowledge by hiring experts allows developers to anticipate and navigate the planning process and regulatory requirements for planning permission, to come up with a strategy and produce a coherent master-plan. By positioning our analysis from the developers' perspective we advance understandings of the role of consultants in informing urban development to suggest that for developers, much of a consultants' value is their ability to help navigate risks and unlock land for development.

In Modderfontein, Zendai hired consultants to advise on every dimension of the project, especially during the masterplanning process. When Zendai kicked-off their scheme in 2014 they put the masterplanning exercise to tender, eventually settling on Atkins Global, a team with international expertise. This was important because it set the context of the development: Zendai wanted to build a new node in the global economy. To do this they needed to create a sense of stability, especially in the face of economic and political uncertainty in South Africa at the time. Further to this, it was anticipated that Atkins would have strong relationships with both the necessary additional consultants in terms of developing a comprehensive planning strategy, and within political institutions. Atkins fulfilled the first role, immediately hiring Collier's International's Destination Team to specifically address the commercial viability. For Colliers the macroeconomy was "the starting point of any analysis" (JBG_Consultant2, 2017), as the consultant went on to elaborate, developers "need to understand the economy - start national - key drivers, how it performs" and then use this broad based knowledge to carry thorough analysis to "exploit the latent and existent strengths" of the economy (JBG_Consultant 2 , 2017). To do this they used data from the 2011 census, a UCT 2004 research report on labour market trends, quarterly labour force survey from South Africa and CIC Construction data from South Africa. Analysis of the macroeconomy was supplemented by information on the local land market during early viability assessment and in total Colliers produced three reports: 'Market Assessment to Inform Development Brief' (March, 2015), 'Options for Modderfontein: Commercial Appraisal' (May, 2015) and 'Commercial Development Framework' (August, 2015). Their analysis operationalised a combination of "extensive quantitative data on Johannesburg real estate" with a 'gut feeling' based on experience and knowing how potential end-users respond (JBG_Consultant3, 2017). This analysis was a vital part of Zendai's strategy because it helped them identify potential economic pitfalls or risks.

Despite this, many of Colliers' suggestions were relatively misplaced, for example they proposed a 'wave lagoon' - an artificial surfing centre - as a potential commercial use, but this was seen by locals as wildly misplaced (JBG_Consultant1,2017) and in doing so Colliers heightened rather than reduced risk. This was partly a reflection of the teams' geography: both Colliers and Atkins were physically based in London and had global experience, which they hoped to leverage in a South African context. Arguably to counter this lack of specific city knowledge within their team, Atkins also brought onboard an Arup team who straddled their London and Johannesburg offices (Brill, 2018). These three teams all worked alongside one another, advising on different components - but the different disciplinary backgrounds inevitably created some tensions, as one consultant highlighted: "You can desire whatever you want from a planning point of view, but ultimately, sooner of later, it comes down to $\mathrm{Mr}$ and Mrs Bloggs deciding whether they're going to purchase an apartment" (JBG_Consultant1, 2017). These tensions translate to risks for developers and despite their army of consultants, Zendai's masterplan was stalled by CoJ, described as "lacking sufficient detail or knowledge" (JBG_Official, 2017). 
Consequently despite having on paper a hugely experienced set of experts, Zendai were unable to translate this into something developable and unlock the land for their project.

The development process, from the developer's perspective, is about managing the various forms of knowledge and facilitating a forum for exchange to inform various aspects of the project: from engagement with local political actors to the development of the masterplan. Therefore, the 'knowledge coalitions' they mobilise have to be inherently multidisciplinary, spanning financial understanding to predict demand and the commercial viability of the scheme (which in turn feed back into design and architectural choices); awareness of local political structures and expectations (to design a scheme that can get political buy in); planning and technical knowledge of the site itself. In strong contrast to Modderfontein, most of the experts hired by Argent to produce the King's Cross Central masterplan were local firms with strong national reputations and deep knowledge of the local political and regulatory context (LDN_Developer, 2016).

The main master planning team was composed of three firms, Allies and Morrisons, Porphyrios Associates and Townsend Landscape Architects, which all previously collaborated in Argent's award winning Brindleyplace scheme in Birmingham (ULI, 2014). From the developer's perspective, working with the masterplanning team that established its reputation was important, and buying in a wide range of experts in the pre-planning phase of the project was instrumental to get planning permission from the council. Argent surrounded itself with an army of specialists, whose expertise ranged from community engagement to planning and architecture, public realm, air quality, environment, infrastructure, and heritage (Robin, 2018 provides an extensive discussion of the key features of this consultants' ecosystem). The hiring of experts also allowed the developers to tap into the firms' networks: a senior executive at the local council (in charge of granting planning permission) was involved in the project and moved to take a leadership position in one of the masterplan's three consultancies a few years after the Argent scheme was granted the green light by the council. Such 'close proximity' between the public sector and the real estate industry in London (including real estate developers, planning consultancies, real estate communication agencies) has been exposed elsewhere (Booth and Crossley, 2018). From the developers' perspective, hiring experts is about getting the best knowledge of and connections with the local context to navigate the planning process and to design a scheme that is commercially viable. Navigating those risks is a key element of long term profit maximization for developers. In the short term, spending money on (expensive, global) consultants reduces profit margins yet the perceived risks of non-compliance with planning regulations as well as risks of misreading the local context outweighs this concern.

The contrasting examples of Modderfontein and Kings Cross illustrate the way different forms of expertise dictate project success, to some extent. In both cases the developers hired extensive networks of consultants since producing more knowledge was expected to reduce risk arising due to regulatory mis-compliance and to the misreading of the local context. However, the contrasting types and geographies of consultants hired shows that developers must ensure consultants have the most locally relevant and context sensitive expertise. Consequently it's evident that the team's composition, in terms of their geography and wider connections, is vital because the developer is constantly navigating the cost of hiring consultants and their added value to the project. At the same time the very existence of a network of actors upon which their plan becomes reliant on for information or connections suggests a devolution of control beyond even the investor relationships highlighted in existing literature and therefore ultimately challenges the idea that they are dominant in all decision-making. Whilst some literature has highlighted that such power shifts have resulted in developers becoming financialised in that they incorporate investor logics into their wider approaches through brokers and consultants because the rely on this information for their revenue (Theurillat and Crevoisier 2013; Halbert and Rouanet 2014; Weber 2015; Guironnet et all., 2016), here we develop on this to highlight the very real work of developers at the centre of this process, at least in our cases. 


\section{Developers as political actors}

As with private sector coalitions, developers must also mitigate risk through coalitions in the political arena (Weinstein, 2014). This requires building strategic alliances with political actors and participating in re-shaping existing institutions to create a supportive environment (Leffers, 2017). The two cases show the importance of bringing on-board local political actors to ensure the risk of project failure through planning denial is curtailed.

Political risk is partly defined by the developers' capacity to navigate the local political context. In Modderfontein this required Zendai to act within CoJ's planning legislation, as well as directly feed into their - at the time being re-drafted - Spatial Development Framework. However, as one consultant described: "They [the City] will never tell you this is what they want. It's more principles, or objectives that need to be achieved"' (JBG_Consultant_5, 2017), there is a vagueness which requires the developers to actively collaborate with the City to understand how policy is applied. Therefore Zendai were required to engage with $\mathrm{CoJ}$ extensively, and this they did through individual issue orientated meetings, 4 large stakeholder workshops during winter 2015 and interim report commenting. However, this form of governance through informality requires some of the developer's ecology of consultants to have a strong relationship with the City, this was not the case for Zendai. Their choice of international consultants combined with their own leadership's lack of local experience meant they did not have the necessary relationships. However, in-house they did have a junior employee who worked to try and mitigate emerging political risks, as he explained "On my side I worked extensively with the council, I handled from our side most of the communication with the council, or some of it at least. Because I know the ladies quite well [..] I had a better networks than other guys" (JBG_Developer_3, June 2017).

That said, his work was insufficient to counter for the actions of others in the Zendai group. The Atkins-led team sought to gain political capital by targeting the provincial level government - Gauteng - a huge political miscalculation which irritated CoJ (Brill, 2018). By seeking to understand Zendai through the lens of risk though, it becomes possible to see this error as even further misplaced: rooted not in political risk but potentially financial risk. Gauteng's Premier announced the Zendai deal to media whilst on a trip in China, independent of any consultation with their staff - "the first we heard was when the phone started ringing" (JBG_GOfficial_2, 2017). Whilst this upset CoJ, it also generated hype and buzz about the site, crafting expectations and arguably potentially cultivating a political space for Chinese capital to land in Johannesburg with more certainty. That said the political reality is that $\mathrm{CoJ}$ is the planning authority, and their policy priorities are addressing the spatial legacy of apartheid through densification and the use of brownfield sites, something which strongly contrasts with the greenfield peripheral development of Modderfontein (Ballard et al., 2017; Brill and Reboredo, 2018). But more than this, the previous owner had isolated CoJ by using, in CoJ's words, "my least favourite town planners" (JBG_Official, 2017). This was accentuated further by the political backdrop: "in the background there's city managers who had their own views on what should or shouldn't happen" who were heavily influencing CoJ's approach and therefore needed to be understood (JBG_Consultant4, 2017). Ultimately continual mismanagement of the political risks undermined the project.

The King's Cross story shows the strategy employed by Argent was more successful. First, it has to be noted that the UK planning system is characterized by its strong emphasis on private sector involvement in regeneration schemes (e.g Edwards, 2009; Colomb, 2007). Consequently, an informal yet long-lasting culture of collaboration has become the norm, where negotiation often takes place at the local level (borough level in London). Whilst, to some extent this is also the case in Johannesburg, where an expected part of planning permission negotiation happens between the local officials and the developer in a quasi-formal setting, the different developer approaches show the striking importance of interpersonal relationships in risk mitigation. In the case of King's Cross, two London Boroughs, 
Camden and Islington, were responsible for granting planning permission although the developer needed to show compliance with a range of national and local regulations (National Planning Guidance, London Plan, Borough-level planning guidance). Responding to planning requirements, the two Boroughs developed their own guidance for the scheme: King's Cross Opportunity Area Planning and Development Brief (2004; referred to as the Joint Planning Brief in what follows) which allowed them to set targets for the developer's final plan (e.g. level of social housing, local jobs creation, provision of healthcare and community facilities, provision of green and public spaces and roads). However, Camden was responsible for granting permission to a much larger part of the Site (the Main Site) and Islington was responsible for granting permission for a smaller section of the whole redevelopment area (the Triangle Site). In addition, Camden, through the establishment of a 'King's Cross Team' to lead negotiations with the developer in 2001 (Bishop and Williams, 2016), quickly positioned itself as the dominating political and administrative authority for the scheme (LDN_Policy Officer, 2016). Given the geographical and administrative importance of Camden for the redevelopment, Argent developed strong working relationship with the King's Cross Team. In addition, a member of the King's Cross Team interviewed for this study highlighted that the creation of the Team was motivated by the willingness of Camden officers to manage the engagement process with the developer. What this meant for Argent in practice was that they were provided with direct access to a dedicated team of lawyers, planners and economists within Camden to "negotiate the outcomes of the scheme" (LDN_Policy Officer, 2016). This was deemed "very helpful in early phases of the project" by Argent, as it allowed them to "clarify expectations" (LDN_Developer_2016). For instance, the developer was heavily involved in the discussions concerning the joint Planning Brief, notably through the King's Cross Team (Robin, 2018). Argent was granted outline planning permission for the Main Site by Camden in 2006 (after revision of their initial proposal submitted in 2004). However, this permission was put on hold when Islington refused to grant Argent planning permission for the Triangle Site, a decision which was eventually overturned by the UK Secretary of State in 2008 following Argent's appeal to the decision, supporting Camden's initial permission and giving the scheme the green light to go ahead. This case highlights that correctly reading the political landscape and balance of power between different jurisdictions early in the redevelopment process is necessary for developers, but also shows that developers cannot fully foresee and mitigate political opposition. Arguably however, forming strategic alliances with local officers early on allowed them to tailor their project in a way that would satisfy some key political actors. Equally, this engagement was facilitated by the Camden council itself, for the set up of a team dedicated to the redevelopment facilitated Argent's ongoing engagement with officers and officials, who "had someone to speak to at every step of the project" (LDN_Policy Officer, 2016).

These two cases reveal that early stages of development require developers to engage in political coalition formation to try and minimise risks associated with planning delays. Even in the case of King's Cross, where the Argent actively engaged with what could appear as the leading politico-administrative force in the process (Camden), further delays were caused by Islington initial refusal to grant permission for the Triangle site. In Modderfontein, the developers, through their consultants, focused their efforts on engaging with the wrong level of government leading to severe delays in the processing of their planning application, and in turn to higher costs and increased uncertainties as to whether the project will be implemented.

\section{Developers as 'community builders'}

Finally, in mitigating project risks, developers engage with local communities. Whilst to some extent this represents a broader part of political risk, we separate them here because the approach of the developers to each type of risk was markedly different. Our analysis revealed that through this work, developers act as 'community builders' to mitigate opposition and to emphasize the legitimacy of their 
scheme. The pitfalls of institutionalized public participation and uneven power balance between public, private and community actors in planning decision-making have been widely explored (e.g Healey, 1998, Raco et al., 2016). This section further highlights that public engagement is a key part of developers' risk management strategies: community opposition, if not dealt with early on, can slow down (and even block) developments (Floricel and Miller, 2001, Kaperson and Kaperson, 2005, Miller and Lessard, 2008) contributing to increasing project costs (Liu et al., 2016) and ultimately undermining financial gains.

In Modderfontein, there was little (local) community objection because the site is largely greenfield. That said, one of Atkins' first actions was to host a two day public exhibition and invite commentary - this formed part of their wider stakeholder meetings which they described as "unusually frank and productive sessions" used to "build early buy-in and consensus" and to "ease potentially problematic conflicts" (Zendai, 2015: 10). As this language suggests, Zendai saw the community management as as a potential issue to be mitigated before it presented a real risk to their project. After these brief engagements, Atkins included a few of the public's comments in their final masterplan, but paid relatively attention to the detail - rather they noted that an essential part of their eventual planning application would be that "they need to be clear in their report" about how they engaged with community (Atkins email, 2015). On the one hand this shows how the participatory approaches in this context were largely driven by planning legislation rather than actual opposition, and on the other that the developer still perceived them to be substantial risks requiring (relatively) expensive engagement processes, albeit resulting in only 6 of the 357 pages of the masterplan addressing the community.

In King's Cross, institutional platforms were set up by the local authorities to facilitate community involvement in the planning process (as required by UK national planning frameworks). In 2002, the Borough of Camden set up the King's Cross Development Forum to allow local communities to follow and comment on Argent's planning application. The developer's communication to this forum was mediated by the King's Cross Team in the Borough of Camden (they provided funding, administrative and logistical support for the Forum). In addition to the Forum, the Boroughs of Camden and Islington both created online mechanisms to collect feedback from local organizations and individuals at various stages of the masterplanning process. Prior to these institutionalized fora, the developer ran its own consultation stream - over a period of two years - which then fed into their master plan. Argent hired a community consultation specialist consultancy to design and implement a large scale community engagement exercise. The three community engagement reports that stemmed from this process emphasized Argent's active involvement in this consultation effort and the presence of senior Argent staff 'on the ground' (Flux, 2004), in particular its figure head, Roger Madelin, interacting directly with local residents. His active involvement was also highlighted by several community organizations interviewed for this study, some of them stressing that "Madelin was a very charming man, always showing up at meetings" but also adding that "the extent to which he listened to us in these meetings is another story" (LDN_Community Group1, 2016).

This case highlights several important elements in relation to developers' role as community builders. For a start, the developer's active role in developing its own consultation mechanisms contributed to shape where and how community opposition could be expressed. Several community organizations which then took the scheme to court in 2006 - deemed that despite these consultations efforts, Argent's proposed scheme did not address their concerns, in particular in relation to the provision of affordable housing in a neighborhood characterized by high levels of depravation (LDN_Community Group1, LDN_Community Group2). When the case was taken to judicial review, Argent dismissed such criticisms highlighting that they were "disappointed with this decision by a small, vocal group of people. Argent and its partners have spent seven years working and consulting on this scheme, talking to thousands of people about the vision and benefits King's Cross Central will bring to the area." (Roger 
Madelin intervention in a local newspaper, 2007). Furthermore, Camden motivated its decision to grant outline planning permission to the project with reference to Argent's commitment to community engagement" "as soon as they started the project they engaged with the community [...] Madelin was everywhere, all the time [...] they made a number of commitments to local communities and sticked to that" (LDN_Policy Officer 2016). Managing contestation risks through engagement with the local population was a key aspect of the developers' strategy to gain planning permission and to minimize contestation voiced outside of this engagement exercise (LDN_Offical, 2016, LDN_Community Group, 2016). Argent's ability to show its early engagement through large scale consultation efforts was instrumental in discarding further oppositions, when the case was taken to court, but also in various media interventions addressing criticisms to the scheme. These efforts were also emphasised by Camden Council, to justify its decision to grant permission to the scheme.

Existing literature on community engagement (or lack thereof) in planning, mainly engages with perspectives from the community and addresses the ability of local groups to influence urban decision making (Healey, 1998). Such studies rarely pay attention to the motives driving the private sectors' involvement with local groups. Our cases show how developers need (legally and strategically) to engage with local communities in order to mitigate project risks. Consequently, real estate developers seek to minimize those risks by engaging with certain parts of the community and spending money (therefore reducing revenues in the short term) on platform creation and public relations, this maximises returns in the long run by avoiding risks associated with strong opposition (which they can easily discard on the grounds that large scale consultation has created a general consensus regarding the redevelopment process, as was the case in King's Cross Central). In contrasting Modderfontein and King's Cross it's possible to see how the process is something relatively predictable, even in cases where the development has little community to engage with, the process of responding to community risk has become standardised. Yet, the actual work and practices of the developer has to be highly localised.

\section{Conclusion}

This paper used the cases of Modderfontein and King's Cross to draw out three conclusions. Firstly, we advanced a wider theoretical conceptualization of risk which builds on existing understandings of risks (their definition and mitigation) as a key aspect of real estate-driven financialization processes, as put forward by David (2012) and Halbert and Rouanet (2014). Our analysis extends their social constructivist understanding by engaging with critical risk studies. We used the resultant understanding of risk to reveal a typology of risks which developers navigate in order to obtain planning permission, as part of project delivery. Developing on the 'range of risks' identified by Halbert and Rouanet (2014) we argue there are three main sources of risk for developers: the lack of locally specific knowledge, misreading the political context, failing to engage with powerful community actors. Importantly, as noted in the analysis section, these categories are not discrete or complete, they merely highlight the breadth of risks shaping real estate projects. With this typology we hope to contribute to a deeper theoretical understanding of what 'what 'risks' are in terms of real estate development' are, how they emerge in specific places and how they shape the different positions developers' occupy within local governance networks. This we believe offers powerful lenses through which one can analyze the geographical implications of financialization.

Secondly and relatedly, we highlighted the diversity of roles developers assume throughout their projects to mitigate the different risks identified: knowledge coordinators, political actors and community builders. In practice these roles often overlap, as was evident in King's Cross, but by creating such a typology of roles we are able to see how the identification and mitigation of risks require developers 
to cultivate their relational networks across different groups of actors, at different scales of interactions. In doing so, we revealed that a risk-based approach to the study of developers integrates the strategic constraints faced by those actors into urban geography research, in a way that is attendant to the relational process by which real estate activities shape sites and localities. This therefore contributes to ongoing research on real estate developers, their strategies, and their influence over urban transformations. Specifically, given the acknowledged position of developers as mediators (see Theurillat et al. 2106) and that their impact on the city is mostly measured through what type and where development occurs, understanding their response to what they see as risks enables more effective planning and control, because it becomes possible to anticipate their strategies and engagement with different types of actors locally (Campbell et al., 2013; Kimelberg, 2011).

Thirdly and relatedly, identifying risk creation and mitigation as inherent to the realization of value in real estate projects is key in understanding how developers mobilize various experts in the transformation of particular places as sites that are suitable for investments and profit generation (Searle, 2014). Building on the idea that developers assume particular roles, through a closer interrogation of the type of experts these roles are dependent on we see how developers make sites that are 'fit for investments'; how developer activities shape (or fail to shape) local political and regulatory landscapes; and finally, how those activities contribute to the marginalization or involvement of local communities in the development process. Whilst this paper has looked into the ways in which risk mitigation is practiced by developers in the pre-planning phases of their (large scale) projects, additional research on the type of networks created in the construction and maintenance phase of the project will likely reveal new patterns of relations and advance the use of a risk-based framework for analysis.

\section{Funding}

The King's Cross research was funded through a research grant from the UK Engineering and Physical Sciences Research Council (EPSRC/1637297). 


\section{References}

Aalbers, Manuel (2015) The Great Moderation, the Great Excess and the global housing crisis, International Journal of Housing Policy, 15:1, 43-60, DOI: 10.1080/14616718.2014.997431

Aalbers, M. B. (2018). Financial geography II: Financial geographies of housing and real estate. Progress in Human Geography, 0309132518819503.

Akers, Joshua. (2015). Emerging market city. Environment and Planning A, 47(9), 1842-1858. doi:10.1177/0308518X15604969

Ascher, Ivan. (2016) Portfolio Society: On the Capitalist Mode of Prediction. New York: Zone Books Ball, Michael. (2006). Markets \& institutions in real estate \& constructionOxford ; Malden, MA Oxford: Oxford ; Malden, MA : Blackwell Pub.

Ballard, Richard, Dittgen, Romain., Harrison Phillip and Todes, Alison (2017). Megaprojects and urban visions: Johannesburg's Corridors of Freedom and Modderfontein. Transformation: Critical Perspectives on Southern Africa 95(1): 111-139.

Bishop, Peter. \& Williams. (2016). Planning, politics and city making : a case study of King's Cross: London : RIBA Publishing.

Blok, A. (2016). Assembling urban riskscapes: Climate adaptation, scales of change and the politics of expertise in Surat, India. City, 20(4), 602-618.

Booth, Robert., \& Crossley, Frankie. (2018). Nearly 100 London councillors have links to property industry. The Guardian. Retrieved from https://www.theguardian.com/society/2018/apr/29/nearly100-london-councillors-have-links-to-property-industry

Brill, Frances (2018) Playing the Game: an international comparison of real estate developers in Modderfontein Johannesburg and London's Royal Docks, Geoforum (2018), https://doi.org/10.1016/j.geoforum.2018.05.015

Brill, Frances. \& Reboredo, Ricardo. (2018). Failed Fantasies in a South African Context: the Case of Modderfontein, Johannesburg. Urban Forum https://doi.org/10.1007/s12132-018-9348-1

Brown, Roger, \& Young, Michael (2011). Coherent risk measures in real estate investment. Journal of Property Investment \& Finance, 29(4/5), 479-493. doi:10.1108/14635781111150358

Callon, Michel (1998). The laws of the markets : edited by Michel Callon. Oxford ; Malden, MA: Oxford ; Blackwell Publishers/The Sociological Review.

Camden, L. B. o. (2004). Camden Unitary Development Plan.

Campbell, Heather, Tait, Malcom, \& Watkins, Craig. (2013). Is There Space for Better Planning in a Neoliberal World? Implications for Planning Practice and Theory. Journal of Planning Education and Research, 34(1), 45-59. doi:10.1177/0739456X13514614

Campkin, Ben (2013). Remaking London : decline and regeneration in urban culture London: London : I.B. Tauris.

Chan, Hei., Li, Shanjun, \& Zhang, Fan (2005). Firm competitiveness and the European Union emissions trading scheme. Energy Policy, 63, 1056.

Chen, Zhen, \& Khumpaisal, Sukulpat (2009). An analytic network process for risks assessment in commercial real estate development. Journal of Property Investment \& Finance, 27(3), 238-258. doi:10.1108/14635780910951957

Christophers, Brett (2014). Wild Dragons in the City: Urban Political Economy, Affordable Housing Development and the Performative World-making of Economic Models. International Journal of Urban and Regional Research, 38(1), 79-97. doi:10.1111/1468-2427.12037

Coiacetto, Eddo. (2001). Diversity in real estate developer behaviour: A case for research. Urban Policy and Research, 19(1), 43-59.

Coiacetto, Eddo, \& Bryant, Lyndall (2014). How Does Access to Development Finance Shape our Cities? Urban Policy and Research, 1-17. doi:10.1080/08111146.2014.924922

Colomb, Claire. (2007). Unpacking new labour's 'Urban Renaissance' agenda: Towards a socially sustainable reurbanization of British cities? Planning Practice \& Research, 22(1), 1-24. doi:10.1080/02697450701455249 
Corpataux, José., Crevoisier, Olivier., \& Theurillat, Thierry. (2009). The Expansion of the Finance Industry and Its Impact on the Economy: A Territorial Approach Based on Swiss Pension Funds. Economic Geography, 85(3), 313-334. doi:10.1111/j.1944-8287.2009.01035.x

Crosby, Neil, \& Henneberry, John (2016). Financialisation, the valuation of investment property and the urban built environment in the UK. Urban Studies, 53(7), 1424-1441. doi:10.1177/0042098015583229

David, Louise. (2012) 'The Social Construction of Real Estate Market Risk. The Case of a Financial Investments Cluster in Mexico City’. Articulo - Journal of Urban Research 9: 1-11.

David and Louise \& Halbert, Ludovic (2014) Financial capital, actor-network theory and the struggle over calculative agencies in the business property markets of Mexico City metropolitan region. Regional Studies 48 (3) :516-29. doi: 10.1080/00343404.2012.756581

Douglas, Mary \& Wildavsky, Aaron (1982). Risk and culture : an essay on the selection of technical and environmental dangers Berkeley ; London : University of California Press.

Edwards, Michael (1992). Microcosm: redevelopment proposals at King's Cross In A. Thornley (Ed.), The Crises of London. London: Routledge.

Edwards, Michael. (2009). King's Cross: renaissance for whom? In J. Punter (Ed.): Routledge.

Fainstein, Susan (2001). The city builders : property development in New York and London, 19802000 (2nd ed., rev. ed.). Lawrence: Lawrence : University Press of Kansas.

Fernandez, Rodrigo., Hofman, Annelore, \& Aalbers, Manuel. B. (2016). London and New York as a safe deposit box for the transnational wealth elite. Environment and Planning A, 48(12), 2443-2461. doi:10.1177/0308518X16659479

Fields, Desiree. (2018). Constructing a New Asset Class: Property- led Financial Accumulation after the Crisis. Economic Geography, 94(2), 118-140. doi:10.1080/00130095.2017.1397492

Fields, Desiree., \& Uffer, Sabina (2016). The financialization of rental housing: A comparative analysis of New York City and Berlin. Urban Studies, 53(7), 1486-1502. doi:10.1177/0042098014543704 Floricel, Serghei, \& Miller, R. (2001). Strategizing for anticipated risks and turbulence in large-scale engineering projects. International Journal of Project Management, 19(8), 445-455. doi:10.1016/S0263-7863(01)00047-3

Flux (2004) Statement of Community Engagement 1, 2, 3 prepared for Argent LLP

French, Nick, \& Gabrielli, Laura (2006). Uncertainty and feasibility studies: an Italian case study. Journal of Property Investment \& Finance, 24(1), 49-67. doi:10.1108/14635780610700732

Garrido, Marco (2013) The Ideology of the Dual City: The Modernist Ethic in the Corporate Development of Makati City, Metro Manila. International Journal of Urban and Regional Research 37(1): 165-85

Geva, Yinnon., \& Rosen, G. (2018). The regeneration deal: Developers, homeowners and new competencies in the development process. Geoforum, 96, 10-20.

Goodchild, Robin, \& Munton, Richard (1985). Development and the landowner : an analysis of the British experience. London: Allen \& Unwin.

Gotham, Kevin. Fox. (2006) The Secondary Circuit of Capital Reconsidered: Globalization and the U.S. Real Estate Sector. American Journal of Sociology 112 (1): 231-75. doi: 10.1086/502695

Gotham, Kevin. Fox. (2009). Creating Liquidity Out of Spatial Fixity: The Secondary Circuit of Capital and the Subprime Mortgage Crisis. International Journal of Urban and Regional Research 33 (2): 355-71. doi: 10.1111/j.1468-2427.2009.00874.x

Gotham, Kevin. Fox (2016). Coastal Restoration as Contested Terrain: Climate Change and the Political Economy of Risk Reduction in Louisiana. Sociological Forum. 31. 10.1111/socf.12273.

Graaskamp, James (1981) Fundamentals of Real Estate Development, Urban Land Institute, Washington D.C

Guironnet, Antoine \& Halbert, Ludovic. (2014) The Financialization of Urban Development Projects: Con- cepts, Processes, and Implications . Working Paper n¹4-04; décembre 2014; 44 pages. 2014. 
Guironnet, Antoine, Halbert, Ludovic, \& Attuyer, Katia. (2016). Building cities on financial assets: The financialization of property markets and its implications for city governments in the Paris cityregion. Urban Studies, 53(7), 1442-1464. doi:10.1177/0042098015576474

Guy, Simon \& Henneberry, John (2002). Development and developers : perspectives on property / Oxford ; Malden, MA Oxford: Oxford ; Malden, MA : Blackwell Science.

Haila, Anne (2016) Urban Land Rent: Singapore as a Property State. Chichester: Wiley

Halbert, Ludovic \& Attuyer, Katia (2016) Introduction: The financialisation of urban production: Conditions, mediations and transformations. Urban Studies. First published online on Feb. 26, 2016. doi:10.1177/0042098016635420A

Halbert, Ludovic., Attuyer, Katia, \& Guironnet, Antoine. (2016). Building cities on financial assets: The financialization of property markets and its implications for city governments in the Paris cityregion. Urban Studies, 53(7), 1442-1464. doi:10.1177/0042098015576474

Halbert, Ludvoic, \& Rouanet, Hortense. (2014). Filtering Risk Away: Global Finance Capital, Transcalar Territorial Networks and the (Un)Making of City-Regions: An Analysis of Business Property Development in Bangalore, India. Regional Studies, 48(3), 471-484. doi:10.1080/00343404.2013.779658

Healey, Patsy (1998). Collaborative Planning in a Stakeholder Society. The Town Planning Review, 69(1), 1-21. doi:10.3828/tpr.69.1.h651u2327m86326p

Henneberry, John, \& Parris, Simon (2013). The embedded developer: using project ecologies to analyse local property development networks. The Town Planning Review, 84(2), 227-249. doi:10.3828/tpr.2013.13

Holgersen, Ståle, \& Haarstad, Håvard (2009). Class, Community and Communicative Planning: Urban Redevelopment at King's Cross, London. Antipode, 41(2), 348-370. doi:10.1111/j.14678330.2009.00676.x

Huffman, Forrest (2003). Corporate real estate risk management and assessment. Journal of Corporate Real Estate, 5(1), 31-41. doi:10.1108/14630010310811984

Hyde, Zachary. (2018). "Giving Back to Get Ahead: Philanthropy as a Developer Strategy of Accumulation in Public-Private Social Housing," Geoforum

Kallman, James (2005). Managing Risk. Risk Management, 52(12), 46.

Kaperson, Jeanne, \& Kaperson, Roger. (2005). The social contours of risk: publics, risk communication and the social amplification of risk. Virginia Earthscan.

Kimelberg, Shelley (2011), Inside the Growth Machine: Real Estate Professionals on the Perceived Challenges of Urban Development. City \& Community, 10: 76-99. doi:10.1111/j.15406040.2010.01351.x

Leffers, Donald. (2017). Real estate developers' influence of land use legislation in the Toronto region: An institutionalist investigation of developers, land conflict and property law. Urban Studies, 0042098017736426. doi:10.1177/0042098017736426

Liu, Ze-Zhio., Zhu, Zheng-wei, Wang, Hui-jia, \& Huang, Jie. (2016). Handling social risks in government- driven mega project: An empirical case study from West China. International Journal of Project Management, 34(2), 202-218. doi:10.1016/j.ijproman.2015.11.003

Lupton, Debroah. (1999). Introduction: risk and sociocultural theory. Cambridge: Cambridge: Cambridge University Press.

Mairal, Gaspar. (2008). Narratives of risk. Journal of Risk Research, 11(1-2), 41-54. doi:10.1080/13669870701521321

Miller, Roger., \& Lessard, Donald (2007). Evolving Strategy: Risk Management and the Shaping of Large Engineering Projects. IDEAS Working Paper Series from RePEc.

Mosselson, Aidan (2017) 'Joburg has its own momentum': towards a vernacular theorisation of urban change. Urban Studies, 54, 1280-1296.

Parkes, Michael (2000). Maintaining the momentum through community activism in Kings Cross.

Local Economy: The Journal of the Local Economy Policy Unit, 15(3), 261-263.

doi:10.1080/02690940050174274 
Papin, Delphine. \& Newman, Peter (2010) De King's Cross à St Pancras, le nouveau quartier de l'Eurostar : géopolitique de 30 ans de conflits. Herodote: revue de geographie et de geopolitique. 137, pp. 93-118.

Peck, Jamie \& Whiteside, Heather (2016) Financializing Detroit, Economic Geography, 92:3, 235268, DOI: $10.1080 / 00130095.2015 .1116369$

Penny, Joe (2017) Between coercion and consent: the politics of "Cooperative Governance" at a time of "Austerity Localism" in London, Urban Geography, 38:9, 1352-1373, DOI 10.1080/02723638.2016.1235932

Pike, Andy \& Pollard, Jane (2010), Economic Geographies of Financialization. Economic Geography, 86: 29-51. doi:10.1111/j.1944-8287.2009.01057.x

Raco, M., Street, E., \& Freire-Trigo, S. (2016). The new localism, anti-political development machines, and the role of planning consultants: Lessons from London's South Bank. Territory, Politics, Governance, 4(2), 216-240.

Rivero, Juan, Teresa, Benjamin, \& West, John. (2017). Locating rationalities in planning: market thinking and its others in the spaces, institutions, and materials of contemporary urban governance. Urban Geography, 38(2), 174-176. doi:10.1080/02723638.2016.1206703

Robin, Enora (2018) Performing real estate value(s): real estate developers, systems of expertise and the production of space Geoforum https://doi.org/10.1016/j.geoforum.2018.05.006

Rosen, Gillad. (2017). Toronto's condo- builders: development approaches and spatial preferences. Urban Geography, 38(4), 606-625. doi:10.1080/02723638.2016.1179426

Rutland, Ted. (2010), The Financialization of Urban Redevelopment. Geography Compass, 4: 11671178. doi:10.1111/j.1749-8198.2010.00348.x

Sanfelici, Daniel \& L. Halbert, Ludovic (2015) Financial markets, developers and housing in Brazil, Urban Studies. First published online on June 19, 2015. doi: 10.1177/0042098015590981.

Searle, Linda (2014). Conflict and Commensuration: Contested Market Making in India's Private Real Estate Development Sector. International Journal of Urban and Regional Research, 38(1), 60-78. doi:10.1111/1468-2427.12042

Shatkin, Gavin (2008). The City and the Bottom Line: Urban Megaprojects and the Privatization of Planning in Southeast Asia. Environment and Planning A, 40(2), 383-401. doi:10.1068/a38439

Smith, Neil (2002). New Globalism, New Urbanism: Gentrification as Global Urban Strategy. Antipode, 34(3), 427-450. doi:10.1111/1467-8330.00249

Teresa, Benjamin (2017). Rationalizing tax increment financing in Chicago. Urban Geography, 38(2), 199-220. doi:10.1080/02723638.2016.1206707

Theurillat, Thierry, and Olivier Crevoisier. (2013). 'The Sustainability of a Financialized Urban Megaproject: The Case of Sihlcity in Zurich'. International Journal of Urban and Regional Research 37 (6): 2052-2073.

Theurillat, T., Vera-Büchel, N., \& Crevoisier, O. (2016). Commentary: From capital landing to urban anchoring: The negotiated city. Urban Studies, 53(7), 1509-1518.

Urban Land Institute. ULI Case Studies. (2014) http://casestudies.uli.org/kings-cross

Vogelpohl, A. (2018). Consulting as a threat to local democracy? Flexible management consultants,

Ward, Callum, and Erik Swyngedouw. 2018. 'Neoliberalisation from the Ground Up: Insurgent Capital, Regional Struggle and the Assetisation of Land'. Antipode 50 (4): 1077-97.

Weber, Rachel (2002). Do Better Contracts Make Better Economic Development Incentives? Journal of the American Planning Association, 68(1), 43-55. doi:10.1080/01944360208977190

Weber, Rachel (2010). Selling City Futures: The Financialization of Urban Redevelopment Policy. Economic Geography, 86(3), 251-274. doi:10.1111/j.1944-8287.2010.01077.x

Weber, Rachel (2015). From boom to bubble : how finance built the new Chicago: Chicago : The University of Chicago Press.

Weinstein, Liza (2014). 'One- Man Handled': Fragmented Power and Political Entrepreneurship in Globalizing Mumbai. International Journal of Urban and Regional Research, 38(1), 14-35. 
Weiss, Marc (1987). The rise of the community builders : the American real estate industry and urban land planning New York ; Guildford: New York ; Guildford : Columbia University Press.

Winarso, Haryo \& Firman, Tommy. (2002). Residential land development in Jabotabek, Indonesia: Triggering economic crisis?. Habitat International. 26. 487-506. 10.1016/S0197-3975(02)00023-1. Zaloom, Caitlin (2003). Ambiguous numbers: trading technologies and interpretation in financial markets. American ethnologist, 30(2), 258-272. 
The risky business of real estate developers: network building and risk mitigation in London and Johannesburg.

Recent work on financialization in urban political economy and economic geography has highlighted real estate developers as a point of analysis for understanding urban governance and ongoing urban restructuring. This paper contributes to this literature by showing how an analytical entry point focused on risks mitigation can help better understand the position of developers in urban governance. In doing so, we call for more geographically sensitive understanding of real estate risk and its influence on developers' strategies in specific places. Building on two examples from Johannesburg and London, this paper highlights the different roles developers assume as knowledge coalition builders, political actors and community builders, to counter threats to the implementation of their projects.

\title{
Keywords:
}

real estate developers - urban governance - risk - urban policy

\section{Corresponding author}

Frances N Brill, Department of Geography, University College London, Pearson Building, Gower Street, Bloomsbury, London WC1E 6BT

\author{
Authors \\ Frances N Brill 1 \\ Enora Robin 2 \\ 1 Department of Geography, Pearson Building, Gower Street, University College London \\ frances.brill@ucl.ac.uk \\ 2 Urban Institute, University of Sheffield
}

\section{Acknowledgements}

The authors would like to thank the anonymous reviewers for their feedback on this paper. We would also like to thank all those who contributed to earlier version of this paper at the 2018 AAG and the London seminar series at the Bartlett School of Planning in October 2018. Frances would also like to thank Professor Jennifer Robinson for all her assistance developing these ideas over the last four years and for her words of encouragement. Special thanks also go to Michael Edwards for his continuing generosity in sharing insights and reflexions on the history of King's Cross Central. Finally, we'd like to thank Joe Penny for introducing us to a wider vocabulary and reminding us of the important questions. 


\section{Introduction}

"If money was no object, any builder would come and build low cost housing but obviously developers are in it for the money - they want money" (JBG_engineer, 2017)

In the aftermath of the 2008 financial crisis, an increasing body of work in critical urban research has explored the ways through which urban development has become financialized (Aalbers, 2018, Aalbers, 2015, Guironnet and Halbert, 2014, Haila, 2016, Halbert and Attuyer, 2016, Peck and Whiteside, 2016, Pike and Pollard, 2010, Rutland, 2010, Weber, 2010). Authors have argued that the increased involvement of global finance in urban developments has been made possible by the development of legal and institutional frameworks that stimulate private sector investments in, and management of, the built environment (Fields, 2018, Weber, 2015, Gotham, 2006, 2009). This has contributed to increasing local governments' reliance on private-led developments to fund core activities (Beswick and Penny, 2018, Robin, 2018, Penny, 2017, Weber, 2002, 2010), for instance through land value capture (Smith, 2002), resulting in growing spatial inequalities and homogenized urban forms (Guironnet and Halbert, 2014). Scholarship has highlighted the key role of intermediaries including brokers, consultants and property developers in anchoring financial capital in particular places (Theurillat et al., 2016) through the transformation of the urban built form and cities' institutional fabric (Brill, 2018; Fernandez et al., 2016, Searle, 2014, Halbert and Rouanet, 2014, David, 2012). Within this literature, real estate developers have been the focus of an increasingly large body of work that shows their role in attracting investments to particular places and their active involvement in urban decision-making (cf. Brill, 2018, Robin, 2018, Geva and Rosen, 2018, Ward and Swyngedouw, 2018, Guironnet et al., 2016, Halbert and Rouanet, 2014, Theurillat and Crevoisier, 2013, Shatkin, 2008, Fainstein, 2001). Within developers' actions to channel mobile capital flows into particular locations, the management and mitigation of a series of investment risks has been shown to influence what gets built and where (Halbert and Rouanet, 2014) as investment choices are themselves shaped by investors' perceptions of a series of risks attached to particular locations (Fields and Uffers, 2016, David, 2012). In other words, as shown by Halbert and Rouanet (2014) the financialisation of urban development requires the constitution and maintenance of trans-scalar territorial networks to support the process of 'filtering risk away' and fixing investments in particular place.

This paper hopes to further build on and advance these discussions, exploring how developers navigate the risks associated with 'landing' in particular places, to bring forth a more nuanced understanding of the process through which these actors shape contemporary urban governance and urban development trajectories. In doing so, we explore the territorial implications of developers' risk mitigation strategies, asking: how can a focus on developers' risk management strategies help elucidate a deeper understanding of the geographical implications of financialization? To address these issues, the next section reviews existing work on developers' activities and argues that these can be better understood through the lens of 'risk' and the imperative of risk mitigation. Drawing on this argument and through a social constructivist understanding of risk we introduce a framework for analyzing developers that is attendant to risk beyond pure 'financial' or investments risks (although we address those), which integrates the importance of localized regulatory and political risks (Searle, 2014, Halbert and Rouanet, 2014). We then illustrate the value of this approach in the study of two large scale urban development projects in Johannesburg and London, highlighting the specific roles developers assume in those cases to mitigate various risks attached to their projects. The last section concludes and discusses further research avenues.

\section{Understanding the work of real estate developers and the role of risk}

Real estate development encompasses a wide range of decisions spread across time and space (cf. Ball, 2006, Graaskamp, 1981), each requiring real estate actors - and developers in particular - to engage 
with global stakeholders and local actors, to differing degrees. This relational work is well understood in the context of developers' political work (Brill, 2018, Hyde, 2018, Weber, 2015, Weinstein, 2014,

The importance of this relational work directs our attention to the kinds of relationships developers have to forge to navigate risks and uncertainties throughout their projects' lifecycle (Chen and Khumpaisal, 2009), for example navigating the tensions of market rationalities (Rivero et al., 2017). In particular, we see how in addition to relationship building with communities and the public sector (Geva and Rosen, 2018, Weiss, 1987), the pre-planning permission stage of a project is also shaped by developers' interactions with investors. This role has been illuminated and analyzed extensively by recent urban political economy research on financialization. This body of work has revealed how, in some cases, the interactions between developers and investors shape what is built and where (Coiacetto and Bryant, 2014) as developers work to make land "fit for investment" (Sanfelici and Halbert, 2016, Searle, 2014, Halbert and Rouanet, 2014). Moreover, as this process is increasingly understood, the importance of interactions with other actors has been revealed to show how real estate is influenced by the work of experts, market analysts and brokers working for investors (Crosby and Henneberry, 2016, Akers, 2015, Searle, 2014, David, 2012, Fainstein, 2001). These actors shape developers' behavior by translating investors' requirements into elements of the project. For instance, highlighting expected rates of returns on investments which then heavily influences both investment location and the content of real estate projects (Crosby and Henneberry, 2016, Halbert and Rouanet, 2014, David and Halbert, 2014).

In a context characterized by the increasing internationalization and financial integration of the real estate industry, global investors bring with them alternative conceptualisations of risk, or what David (2012) and Corpataux et al (2009) note are 'new perceptions' of risk (for a discussion of the political economy of different perceptions of risk see Gotham, 2016). As such, of particular importance in financialised settings and locations where investors are from abroad, is the developer's role in helping shape and mitigate potential risks (cf. Geva and Rosen, 2018, Rosen 2017, David, 2012,). Responding to this, recent literature has shown how developers shape the way investors experience the risk of investing in particular cities or projects. Seminal in this work is David's (2012) study of Mexico City. Through her institutionalist analysis she demonstrates the territorialised nature of financial flows in real estate. Specifically, by analyzing how a relatively 'new' market for international investors shifted over time from being 'took risky' to manageable, David (2012) highlights how developers shape investors' perceptions of the risks attached to investing in particular locations. In doing so she encourages analysis to look at non-financial actors (for example, developers) who work to transform markets. David's (2012) analysis directly speaks to Halbert and Rouanet's (2014) work on Bangalore. They show, in their words, how local and regional real estate actors, including developers, 'filter away' the risks of real estate in Bangalore. These actors make land legible to international investors and through this mediate expectations (see also Guironnet et al., 2016 for a discussion of these issues in the Paris region). The authors show how land assembly practices and the standardisation of data for international investors contribute to this process of filtering risk away. These two case studies are vital in understanding development risk, as their authors demonstrate how developers internalize investors' definitions of risks into their strategies on the ground and at different scales of governance (from the local to the global). 
In our work, we draw on both David (2012) and Halbert and Rouanet (2014) to elucidate how real estate professionals manage 'risk'. However, we depart from their approaches by moving beyond a focus on financial risks related to expected returns for investors to integrate other dimensions of risks, as perceived and experienced by developers themselves. As Halbert and Rouanet explain their work is concerned with how "from an investor perspective, the real estate industry absorbs a series of risks associated with the local-regional institutional workings that characterize land and business property development markets" (2104: 479). In this paper we respond to this, continuing an analysis of the series of risk but from a developer's perspective that highlights the localized production of risk. We therefore look at how market and development risks emerge in particular places, which in turn shape how risks manifest and influence developers' strategies. In this endeavour we draw on David's social constructivist understanding of risk which demonstrates "the need to develop approaches that consider that economic practices embody economic, social, political and cultural logics at the same time" (2012: 35), practices which in turn are embedded in particular places. This calls for a better conceptualization of the work risk does and how it shapes developers actions in different locations. In particular, it requires us to explore how risk is understood and perceived by developers themselves as these land in particular places, and how their territorialized relational strategies are guided by such perceptions.

Risk is both a relatively predictable dimension of a real estate project, and a relatively subjective notion grounded in individual experiences and perceptions. In technical and economic studies, risk is portrayed as a predictable dimension of project management, commonly accepted as the variation from expected outcome, where expected outcome is based on past experiences' average (Kallman, 2005). Following this, in practice, analysts typically apply this definition of risk to a project through ratios which compare projects to alternatives and measure the relative deviance between different scenari. This classical narrative dominates financial, project management and neoclassical economics studies of risk, which are widely used in the real estate industry and portfolio management. Building on this, as is revealed through recent political economy analysis, portfolio management, through risk diversification, has become a core component of value generation in financialised societies (Ascher, 2016, David, 2012, Corpotaux et al., 2009). In the context of real estate, existing research from project management studies highlights key dimensions of supposed objective risk including financial risks, physical risks and regulatory risks (Huffman, 2003). Additionally, Chan et al., (2005) also argue environmental and social risks are likely to affect a project's expected returns on investments.

Political and regulatory challenges are further explored in Kimelberg's (2011) assessment of the challenges developers face. Her work highlights the following potential risks: the importance of re-election for local politicians, the interest of local municipality staff, zoning regulations; and orchestrated community push-backs (ibid.). Experts work hand in hand with real estate developers to identify such risks, to anticipate their likelihood, to assess their impact on real estate markets behaviour and project viability, and to develop mitigation strategies, for instance through the production of "risk matrices" and "financial viability assessments" (Robin, 2018, Henneberry and Crosby, 2016, French and Gabrielli, 2006) The employment of such techniques in turn influences the location and geography of investment in real estate, as well as the type of projects that eventually gets built - e.g. mixed-use schemes evident globally (Guironnet and Halbert, 2014). However, real estate projects and the risks they entail are not purely (if at all) the product of rational decisions or events that can be modelled and predicted, because they are embedded in the messy socio-economic and cultural context of their location. As such, research has shown that understandings of risks resting on quantification - and the meaning associated with probabilistic metrics - is mediated by interpretative work that is socially and spatially grounded (see Zaloom, 2003 for a discussion of "ambiguous numbers" and decision making on financial markets, David, 2012). Real estate developers therefore know that every project carries "uncertainties and risks that cannot be predicted", especially in long-term large scale redevelopment projects (LDN_Developer, 2016). 
Following on from this, risk itself, whilst a relatively objective calculation for some real estate professionals, must be acknowledged as something which is not experienced homogeneously (Brown and Young 2011). Investors and developers' appreciation of risk is subject to individual bias where the identification, definition, evaluation, perception of and reaction to risks is context-specific. Such differentiated experiences of risk emphasize environmental factors and in turn influence decision-making in uncertain situations (cf. Douglas and Wildavsky, 1982). Social constructivist analysis has shown risk to be embedded in specific socio-cultural contexts, highlighting that understandings of risks, and risks themselves, are socially constructed, negotiated, contested, reconfigured and mediated, notably through the work of experts (David, 2012), but not only (Blok, 2016). In that sense, "there is a continual definitional struggle over risk [...] as a result, risk has become a highly politicized concept" (Lupton, 1999, 68). Mairal offers a particularly insightful way of engaging with risk in comparative and relational studies of real estate: recognising the relational nature of development, he sees risk as "a frame that creates contexts which bring together an 'object of risk' (a hazard or source of potential harm), an 'object at risk' (a target of potential harm) and an evaluation (implicit or explicit) of human consequences" (2008, p. 42). This leads us to argue that real estate developers, when they land in particular places, engage in relational work to identify objects of risks (attached to the local context) and to gain knowledge about the likelihood and impacts of those on their projects (the object at risk). Risks definition, anticipation and mitigation can be seen, in that sense, as relational and geographically embedded.

We take this proposition forward in what follows, mobilizing risk as an analytical entry point to understand real estate developers' behavior. This, we argue, enables a deeper understanding of the territorialized nature of real estate development processes. The next sections exemplify the value of this approach through the study of private developers ${ }^{1}$ activities in two large-scale redevelopment projects in London and Johannesburg. Our comparison focuses on developers' strategies in relation to three specific categories of risks (1) those related to the local market, (2) the political environment and (3) the strength of local communities. In direct response to these, our research finds developers enact different roles in local governance settings, that of (a) coordinators of knowledge in and about particular locations; (b) political actors; (c) and community builders.

\section{Introducing our cases: Modderfontein, Johannesburg and Kings Cross, London}

This paper generates insights on developers' role in local governance by looking at how they identify and navigate different risks in two large scale redevelopments: Modderfontein in Johannesburg and King's Cross Central London. We explore these issues within a specific timeframe: the pre-planning phase of both redevelopment projects. The findings presented in this paper result from ongoing collaboration between the two authors, and highlight the value of speaking across two cities, especially two sites which at first sight might seem to have little in common. However, Modderfontein and King's Cross Central are both historically significant areas: the King's Cross Railway Lands were a core site of industrial London and Modderfontein is home to an explosives factory which enabled Johannesburg's mining industry. Arguably, given the strategic importance of London as a base for Britain's global trade and Johannesburg as a mining city, without these sites neither city would have the global position they occupy today. Their shared strategic significance is something local authorities were keen to take advantage of and, as such, both mega-projects received extensive attention from governments (local and national), investors and the media.

\footnotetext{
${ }^{1}$ We contend that the developers leading such projects are not representative of all developers - given the large variety in types of developers shaping urban transformations - but they nonetheless represent a relevant entry point to understand how international financial capital gets channeled into the built environment and shapes contemporary urban trajectories.
} 
Modderfontein is the largest plot of land left in the great Johannesburg region and was purchased in 2012 from a local developer, Heartland, by Zendai, a Shanghai developer who wanted to build a new from the Chinese market and seize the opportunities offered elsewhere: it was an entirely new type and location of venture for them. Unlike many developers in the Global South, Zendai were not tied to political actors or the state itself (Shatkin, 2014), oligarchs (Winarso and Firman, 2002) or from financially important families in the city (Garrido, 2013), and this lack of connections is vital in understanding how the process unfolded in terms of their capacity to leverage material and political connections to cultivate land for development. Zendai's proposal was announced by provincial government, Gauteng Province, and at the same time local media outlets spread the news of a 87billion ZAR investment fund. In the face of this political buzz, Zendai wanted to capitalize on the opportunity to engage with an international team so in 2015 a 'global' team, primarily from London, were hired to produce a masterplan. Findings from this case are based on 48 interviews with people who worked for Zendai between 2012 and 2016 in their planning department, environmental team and finance department, as well as the development lead; their consultant team in London and Johannesburg; employees of the City of Johannesburg's (CoJ) planning department; and Gauteng officials. These interviews focused on the Zendai's strategies: their objectives, how these evolved over the course of their project, their everyday actions, who and how they interacted with different people in the planning application process and what information they used to inform their perspectives. These interviews were read alongside Johannesburg's Spatial Development Framework; internal commercial reporting; interim masterplan feedback between CoJ and Zendai, and the eventual masterplan.

King's Cross Central is one of the largest redevelopments in Central London. Since the 1980s, the site was on the radar of national and local government, regarded as a prime opportunity for new office space in the crowded British capital, and for increasing housing provision (Parkes, 2000; London Borough of Camden, 2004). After attempted development in the 1990s, pre-crash of the property market, the early 2000s were marked by the appointment of Argent as a developer for the site. The masterplan for the site was approved in 2006 and construction work started in 2007. The scheme has been the subject of numerous academic inquiries, exposing its conflictual nature (Papin and Newman, 2010), and notably investigating how, because of its inherently commercial nature, it failed in integrating the needs of local communities (Edwards, 1992, 2009; Parkes, 2000; Holgersen and Haarstad, 2009; Campkin, 2013). The study focuses on the 2000-2006 period during which the planning application for the main area of the King's Cross site was developed, revised and approved. The findings proceed from interviews $(n=18)$ with key informants involved in the planning process (developers, architects, consultants, politicians, community groups and local authorities at the Borough and Metropolitan level) and from the analysis of all planning documents and supporting evidence produced between 2000 and 2006 by the developer and the consultants it hired; minutes from 26 meetings from the King's Cross Development Forum (umbrella organization for local community groups) between 2002 and 2006 which capture some of the key controversies that emerged in the masterplanning process, including communities' concerns vis-à-vis the developer strategy; and of news articles and consultation documents (e.g. community responses to the different versions of the masterplan submitted by the developer). The interviews focused on exploring the importance of the knowledge production process in mitigating development risks, the developer (and its team) relationship vis-à-vis public, private and community stakeholders and how different actors perceived re-development risks. The document and minutes review explored how redevelopment risks were framed, known and acted upon, and which challenges emerged for the developer in the formulation of risk-mitigation strategies. 


\section{Risk mitigation in action: tracing developers' networks in Johannesburg and London}

\section{Developers as knowledge-coalition builders}

When beginning a project developers need to source knowledge from an extensive web of consultants to investigate the sites' specificities and economic opportunities, as well as the legal and political context. Building on existing research highlighting the power of consultancies in urban decision-making (Fainstein, 2001), our research highlights how generating knowledge by hiring experts allows developers to anticipate and navigate the planning process and regulatory requirements for planning permission, to come up with a strategy and produce a coherent master-plan. By positioning our analysis from the developers' perspective we advance understandings of the role of consultants in informing urban development to suggest that for developers, much of a consultants' value is their ability to help navigate risks and unlock land for development.

In Modderfontein, Zendai hired consultants to advise on every dimension of the project, especially during the masterplanning process. When Zendai kicked-off their scheme in 2014 they put the masterplanning exercise to tender, eventually settling on Atkins Global, a team with international expertise. This was important because it set the context of the development: Zendai wanted to build a new node in the global economy. To do this they needed to create a sense of stability, especially in the face of economic and political uncertainty in South Africa at the time. Further to this, it was anticipated that Atkins would have strong relationships with both the necessary additional consultants in terms of developing a comprehensive planning strategy, and within political institutions. Atkins fulfilled the first role, immediately hiring Collier's International's Destination Team to specifically address the commercial viability. For Colliers the macroeconomy was "the starting point of any analysis" (JBG_Consultant2, 2017), as the consultant went on to elaborate, developers "need to understand the economy - start national - key drivers, how it performs" and then use this broad based knowledge to carry thorough analysis to "exploit the latent and existent strengths" of the economy (JBG_Consultant2, 2017). To do this they used data from the 2011 census, a UCT 2004 research report on labour market trends, quarterly labour force survey from South Africa and CIC Construction data from South Africa. Analysis of the macroeconomy was supplemented by information on the local land market during early viability assessment and in total Colliers produced three reports: 'Market Assessment to Inform Development Brief' (March, 2015), 'Options for Modderfontein: Commercial Appraisal' (May, 2015) and 'Commercial Development Framework' (August, 2015). Their analysis operationalised a combination of "extensive quantitative data on Johannesburg real estate" with a 'gut feeling' based on experience and knowing how potential end-users respond (JBG_Consultant3, 2017). This analysis was a vital part of Zendai's strategy because it helped them identify potential economic pitfalls or risks.

Despite this, many of Colliers' suggestions were relatively misplaced, for example they proposed a 'wave lagoon' - an artificial surfing centre - as a potential commercial use, but this was seen by locals as wildly misplaced (JBG_Consultant1,2017) and in doing so Colliers heightened rather than reduced risk. This was partly a reflection of the teams' geography: both Colliers and Atkins were physically based in London and had global experience, which they hoped to leverage in a South African context. Arguably to counter this lack of specific city knowledge within their team, Atkins also brought onboard an Arup team who straddled their London and Johannesburg offices (Brill, 2018). These three teams all worked alongside one another, advising on different components - but the different disciplinary backgrounds inevitably created some tensions, as one consultant highlighted: "You can desire whatever you want from a planning point of view, but ultimately, sooner of later, it comes down to $\mathrm{Mr}$ and Mrs Bloggs deciding whether they're going to purchase an apartment" (JBG_Consultant1, 2017). These tensions translate to risks for developers and despite their army of consultants, Zendai's masterplan was stalled by CoJ, described as "lacking sufficient detail or knowledge" (JBG_Official, 2017). 
Consequently despite having on paper a hugely experienced set of experts, Zendai were unable to translate this into something developable and unlock the land for their project.

The development process, from the developer's perspective, is about managing the various forms of knowledge and facilitating a forum for exchange to inform various aspects of the project: from engagement with local political actors to the development of the masterplan. Therefore, the 'knowledge coalitions' they mobilise have to be inherently multidisciplinary, spanning financial understanding to predict demand and the commercial viability of the scheme (which in turn feed back into design and architectural choices); awareness of local political structures and expectations (to design a scheme that can get political buy in); planning and technical knowledge of the site itself. In strong contrast to Modderfontein, most of the experts hired by Argent to produce the King's Cross Central masterplan were local firms with strong national reputations and deep knowledge of the local political and regulatory context (LDN_Developer, 2016).

The main master planning team was composed of three firms, Allies and Morrisons, Porphyrios Associates and Townsend Landscape Architects, which all previously collaborated in Argent's award winning Brindleyplace scheme in Birmingham (ULI, 2014). From the developer's perspective, working with the masterplanning team that established its reputation was important, and buying in a wide range of experts in the pre-planning phase of the project was instrumental to get planning permission from the council. Argent surrounded itself with an army of specialists, whose expertise ranged from community engagement to planning and architecture, public realm, air quality, environment, infrastructure, and heritage (Robin, 2018 provides an extensive discussion of the key features of this consultants' ecosystem). The hiring of experts also allowed the developers to tap into the firms' networks: a senior executive at the local council (in charge of granting planning permission) was involved in the project and moved to take a leadership position in one of the masterplan's three consultancies a few years after the Argent scheme was granted the green light by the council. Such 'close proximity' between the public sector and the real estate industry in London (including real estate developers, planning consultancies, real estate communication agencies) has been exposed elsewhere (Booth and Crossley, 2018). From the developers' perspective, hiring experts is about getting the best knowledge of and connections with the local context to navigate the planning process and to design a scheme that is commercially viable. Navigating those risks is a key element of long term profit maximization for developers. In the short term, spending money on (expensive, global) consultants reduces profit margins yet the perceived risks of non-compliance with planning regulations as well as risks of misreading the local context outweighs this concern.

The contrasting examples of Modderfontein and Kings Cross illustrate the way different forms of expertise dictate project success, to some extent. In both cases the developers hired extensive networks of consultants since producing more knowledge was expected to reduce risk arising due to regulatory mis-compliance and to the misreading of the local context. However, the contrasting types and geographies of consultants hired shows that developers must ensure consultants have the most locally relevant and context sensitive expertise. Consequently it's evident that the team's composition , in terms of their geography and wider connections, is vital because the developer is constantly navigating the cost of hiring consultants and their added value to the project. At the same time the very existence of a network of actors upon which their plan becomes reliant on for information or connections suggests a devolution of control beyond even the investor relationships highlighted in existing literature and therefore ultimately challenges the idea that they are dominant in all decision-making. Whilst some literature has highlighted that such power shifts have resulted in developers becoming financialised in that they incorporate investor logics into their wider approaches through brokers and consultants because the rely on this information for their revenue (Theurillat and Crevoisier 2013; Halbert and Rouanet 2014; Weber 2015; Guironnet et all., 2016), here we develop on this to highlight the very real work of developers at the centre of this process, at least in our cases. 


\section{Developers as political actors}

As with private sector coalitions, developers must also mitigate risk through coalitions in the political arena (Weinstein, 2014). This requires building strategic alliances with political actors and participating in re-shaping existing institutions to create a supportive environment (Leffers, 2017). The two cases show the importance of bringing on-board local political actors to ensure the risk of project failure through planning denial is curtailed.

Political risk is partly defined by the developers' capacity to navigate the local political context. In Modderfontein this required Zendai to act within CoJ's planning legislation, as well as directly feed into their - at the time being re-drafted - Spatial Development Framework. However, as one consultant described: "They [the City] will never tell you this is what they want. It's more principles, or objectives that need to be achieved"' (JBG_Consultant_5, 2017), there is a vagueness which requires the developers to actively collaborate with the City to understand how policy is applied. Therefore Zendai were required to engage with $\mathrm{CoJ}$ extensively, and this they did through individual issue orientated meetings, 4 large stakeholder workshops during winter 2015 and interim report commenting. However, this form of governance through informality requires some of the developer's ecology of consultants to have a strong relationship with the City, this was not the case for Zendai. Their choice of international consultants combined with their own leadership's lack of local experience meant they did not have the necessary relationships. However, in-house they did have a junior employee who worked to try and mitigate emerging political risks, as he explained "On my side I worked extensively with the council, I handled from our side most of the communication with the council, or some of it at least. Because I know the ladies quite well [..] I had a better networks than other guys"'(JBG_Developer_3, June 2017).

That said, his work was insufficient to counter for the actions of others in the Zendai group. The Atkins-led team sought to gain political capital by targeting the provincial level government - Gauteng - a huge political miscalculation which irritated CoJ (Brill, 2018). By seeking to understand Zendai through the lens of risk though, it becomes possible to see this error as even further misplaced: rooted not in political risk but potentially financial risk. Gauteng's Premier announced the Zendai deal to media whilst on a trip in China, independent of any consultation with their staff - "the first we heard was when the phone started ringing" (JBG_GOfficial_2,2017). Whilst this upset CoJ, it also generated hype and buzz about the site, crafting expectations and arguably potentially cultivating a political space for Chinese capital to land in Johannesburg with more certainty. That said the political reality is that $\mathrm{CoJ}$ is the planning authority, and their policy priorities are addressing the spatial legacy of apartheid through densification and the use of brownfield sites, something which strongly contrasts with the greenfield peripheral development of Modderfontein (Ballard et al., 2017; Brill and Reboredo, 2018). But more than this, the previous owner had isolated CoJ by using, in CoJ's words, "my least favourite town planners" (JBG_Official, 2017). This was accentuated further by the political backdrop: "in the background there's city managers who had their own views on what should or shouldn't happen" who were heavily influencing CoJ's approach and therefore needed to be understood (JBG_Consultant4, 2017). Ultimately continual mismanagement of the political risks undermined the project.

The King's Cross story shows the strategy employed by Argent was more successful. First, it has to be noted that the UK planning system is characterized by its strong emphasis on private sector involvement in regeneration schemes (e.g Edwards, 2009; Colomb, 2007). Consequently, an informal yet long-lasting culture of collaboration has become the norm, where negotiation often takes place at the local level (borough level in London). Whilst, to some extent this is also the case in Johannesburg, where an expected part of planning permission negotiation happens between the local officials and the developer in a quasi-formal setting, the different developer approaches show the striking importance of interpersonal relationships in risk mitigation. In the case of King's Cross, two London Boroughs, 
Camden and Islington, were responsible for granting planning permission although the developer needed to show compliance with a range of national and local regulations (National Planning Guidance, London Plan, Borough-level planning guidance). Responding to planning requirements, the two Boroughs developed their own guidance for the scheme: King's Cross Opportunity Area Planning and Development Brief (2004; referred to as the Joint Planning Brief in what follows) which allowed them to set targets for the developer's final plan (e.g. level of social housing, local jobs creation, provision of healthcare and community facilities, provision of green and public spaces and roads). However, Camden was responsible for granting permission to a much larger part of the Site (the Main Site) and Islington was responsible for granting permission for a smaller section of the whole redevelopment area (the Triangle Site). In addition, Camden, through the establishment of a 'King's Cross Team' to lead negotiations with the developer in 2001 (Bishop and Williams, 2016), quickly positioned itself as the dominating political and administrative authority for the scheme (LDN_Policy Officer, 2016). Given the geographical and administrative importance of Camden for the redevelopment, Argent developed strong working relationship with the King's Cross Team. In addition, a member of the King's Cross Team interviewed for this study highlighted that the creation of the Team was motivated by the willingness of Camden officers to manage the engagement process with the developer. What this meant for Argent in practice was that they were provided with direct access to a dedicated team of lawyers, planners and economists within Camden to "negotiate the outcomes of the scheme" (LDN_Policy Officer, 2016). This was deemed "very helpful in early phases of the project" by Argent, as it allowed them to "clarify expectations" (LDN_Developer_2016). For instance, the developer was heavily involved in the discussions concerning the joint Planning Brief, notably through the King's Cross Team (Robin, 2018). Argent was granted outline planning permission for the Main Site by Camden in 2006 (after revision of their initial proposal submitted in 2004). However, this permission was put on hold when Islington refused to grant Argent planning permission for the Triangle Site, a decision which was eventually overturned by the UK Secretary of State in 2008 following Argent's appeal to the decision, supporting Camden's initial permission and giving the scheme the green light to go ahead. This case highlights that correctly reading the political landscape and balance of power between different jurisdictions early in the redevelopment process is necessary for developers, but also shows that developers cannot fully foresee and mitigate political opposition. Arguably however, forming strategic alliances with local officers early on allowed them to tailor their project in a way that would satisfy some key political actors. Equally, this engagement was facilitated by the Camden council itself, for the set up of a team dedicated to the redevelopment facilitated Argent's ongoing engagement with officers and officials, who "had someone to speak to at every step of the project" (LDN_Policy Officer, 2016).

These two cases reveal that early stages of development require developers to engage in political coalition formation to try and minimise risks associated with planning delays. Even in the case of King's Cross, where the Argent actively engaged with what could appear as the leading politico-administrative force in the process (Camden), further delays were caused by Islington initial refusal to grant permission for the Triangle site. In Modderfontein, the developers, through their consultants, focused their efforts on engaging with the wrong level of government leading to severe delays in the processing of their planning application, and in turn to higher costs and increased uncertainties as to whether the project will be implemented.

\section{Developers as 'community builders'}

Finally, in mitigating project risks, developers engage with local communities. Whilst to some extent this represents a broader part of political risk, we separate them here because the approach of the developers to each type of risk was markedly different. Our analysis revealed that through this work, developers act as 'community builders' to mitigate opposition and to emphasize the legitimacy of their 
scheme. The pitfalls of institutionalized public participation and uneven power balance between public, private and community actors in planning decision-making have been widely explored (e.g Healey,

In King's Cross, institutional platforms were set up by the local authorities to facilitate community involvement in the planning process (as required by UK national planning frameworks). In 2002, the Borough of Camden set up the King's Cross Development Forum to allow local communities to follow and comment on Argent's planning application. The developer's communication to this forum was mediated by the King's Cross Team in the Borough of Camden (they provided funding, administrative and logistical support for the Forum). In addition to the Forum, the Boroughs of Camden and Islington both created online mechanisms to collect feedback from local organizations and individuals at various stages of the masterplanning process. Prior to these institutionalized fora, the developer ran its own consultation stream - over a period of two years - which then fed into their master plan. Argent hired a community consultation specialist consultancy to design and implement a large scale community engagement exercise. The three community engagement reports that stemmed from this process emphasized Argent's active involvement in this consultation effort and the presence of senior Argent staff 'on the ground' (Flux, 2004), in particular its figure head, Roger Madelin, interacting directly with local residents. His active involvement was also highlighted by several community organizations interviewed for this study, some of them stressing that "Madelin was a very charming man, always showing up at meetings" but also adding that "the extent to which he listened to us in these meetings is another story" (LDN_Community Group1, 2016).

This case highlights several important elements in relation to developers' role as community builders. For a start, the developer's active role in developing its own consultation mechanisms contributed to shape where and how community opposition could be expressed. Several community organizations which then took the scheme to court in 2006 - deemed that despite these consultations efforts, Argent's proposed scheme did not address their concerns, in particular in relation to the provision of affordable housing in a neighborhood characterized by high levels of depravation (LDN_Community Group1, LDN_Community Group2). When the case was taken to judicial review, Argent dismissed such criticisms highlighting that they were "disappointed with this decision by a small, vocal group of people. Argent and its partners have spent seven years working and consulting on this scheme, talking to thousands of people about the vision and benefits King's Cross Central will bring to the area." (Roger 
Madelin intervention in a local newspaper, 2007). Furthermore, Camden motivated its decision to grant outline planning permission to the project with reference to Argent's commitment to community engagement" "as soon as they started the project they engaged with the community [...] Madelin was everywhere, all the time [...] they made a number of commitments to local communities and sticked to that" (LDN_Policy Officer 2016). Managing contestation risks through engagement with the local population was a key aspect of the developers' strategy to gain planning permission and to minimize contestation voiced outside of this engagement exercise (LDN_Offical, 2016, LDN_Community Group, 2016). Argent's ability to show its early engagement through large scale consultation efforts was instrumental in discarding further oppositions, when the case was taken to court, but also in various media interventions addressing criticisms to the scheme. These efforts were also emphasised by Camden Council, to justify its decision to grant permission to the scheme.

Existing literature on community engagement (or lack thereof) in planning, mainly engages with perspectives from the community and addresses the ability of local groups to influence urban decision making (Healey, 1998). Such studies rarely pay attention to the motives driving the private sectors' involvement with local groups. Our cases show how developers need (legally and strategically) to engage with local communities in order to mitigate project risks. Consequently, real estate developers seek to minimize those risks by engaging with certain parts of the community and spending money (therefore reducing revenues in the short term) on platform creation and public relations, this maximises returns in the long run by avoiding risks associated with strong opposition (which they can easily discard on the grounds that large scale consultation has created a general consensus regarding the redevelopment process, as was the case in King's Cross Central). In contrasting Modderfontein and King's Cross it's possible to see how the process is something relatively predictable, even in cases where the development has little community to engage with, the process of responding to community risk has become standardised. Yet, the actual work and practices of the developer has to be highly localised.

\section{Conclusion}

This paper used the cases of Modderfontein and King's Cross to draw out three conclusions. Firstly, we advanced a wider theoretical conceptualization of risk which builds on existing understandings of risks (their definition and mitigation) as a key aspect of real estate-driven financialization processes, as put forward by David (2012) and Halbert and Rouanet (2014). Our analysis extends their social constructivist understanding by engaging with critical risk studies. We used the resultant understanding of risk to reveal a typology of risks which developers navigate in order to obtain planning permission, as part of project delivery. Developing on the 'range of risks' identified by Halbert and Rouanet (2014) we argue there are three main sources of risk for developers: the lack of locally specific knowledge, misreading the political context, failing to engage with powerful community actors. Importantly, as noted in the analysis section, these categories are not discrete or complete, they merely highlight the breadth of risks shaping real estate projects. With this typology we hope to contribute to a deeper theoretical understanding of what 'what 'risks' are in terms of real estate development' are, how they emerge in specific places and how they shape the different positions developers' occupy within local governance networks. This we believe offers powerful lenses through which one can analyze the geographical implications of financialization.

Secondly and relatedly, we highlighted the diversity of roles developers assume throughout their projects to mitigate the different risks identified: knowledge coordinators, political actors and community builders. In practice these roles often overlap, as was evident in King's Cross, but by creating such a typology of roles we are able to see how the identification and mitigation of risks require developers 
to cultivate their relational networks across different groups of actors, at different scales of interactions. In doing so, we revealed that a risk-based approach to the study of developers integrates the strategic constraints faced by those actors into urban geography research, in a way that is attendant to the relational process by which real estate activities shape sites and localities. This therefore contributes to ongoing research on real estate developers, their strategies, and their influence over urban transformations. Specifically, given the acknowledged position of developers as mediators (see Theurillat et al. 2106) and that their impact on the city is mostly measured through what type and where development occurs, understanding their response to what they see as risks enables more effective planning and control, because it becomes possible to anticipate their strategies and engagement with different types of actors locally (Campbell et al., 2013; Kimelberg, 2011).

Thirdly and relatedly, identifying risk creation and mitigation as inherent to the realization of value in real estate projects is key in understanding how developers mobilize various experts in the transformation of particular places as sites that are suitable for investments and profit generation (Searle, 2014). Building on the idea that developers assume particular roles, through a closer interrogation of the type of experts these roles are dependent on we see how developers make sites that are 'fit for investments'; how developer activities shape (or fail to shape) local political and regulatory landscapes; and finally, how those activities contribute to the marginalization or involvement of local communities in the development process. Whilst this paper has looked into the ways in which risk mitigation is practiced by developers in the pre-planning phases of their (large scale) projects, additional research on the type of networks created in the construction and maintenance phase of the project will likely reveal new patterns of relations and advance the use of a risk-based framework for analysis.

\section{Funding}

The King's Cross research was funded through a research grant from the UK Engineering and Physical Sciences Research Council (EPSRC/1637297). 


\section{References}

Aalbers, Manuel (2015) The Great Moderation, the Great Excess and the global housing crisis, International Journal of Housing Policy, 15:1, 43-60, DOI: 10.1080/14616718.2014.997431

Aalbers, M. B. (2018). Financial geography II: Financial geographies of housing and real estate. Progress in Human Geography, 0309132518819503.

Akers, Joshua. (2015). Emerging market city. Environment and Planning A, 47(9), 1842-1858. doi:10.1177/0308518X15604969

Ascher, Ivan. (2016) Portfolio Society: On the Capitalist Mode of Prediction. New York: Zone Books Ball, Michael. (2006). Markets \& institutions in real estate \& constructionOxford ; Malden, MA Oxford: Oxford ; Malden, MA : Blackwell Pub.

Ballard, Richard, Dittgen, Romain., Harrison Phillip and Todes, Alison (2017). Megaprojects and urban visions: Johannesburg's Corridors of Freedom and Modderfontein. Transformation: Critical Perspectives on Southern Africa 95(1): 111-139.

Bishop, Peter. \& Williams. (2016). Planning, politics and city making : a case study of King's Cross: London : RIBA Publishing.

Blok, A. (2016). Assembling urban riskscapes: Climate adaptation, scales of change and the politics of expertise in Surat, India. City, 20(4), 602-618.

Booth, Robert., \& Crossley, Frankie. (2018). Nearly 100 London councillors have links to property industry. The Guardian. Retrieved from https://www.theguardian.com/society/2018/apr/29/nearly100-london-councillors-have-links-to-property-industry

Brill, Frances (2018) Playing the Game: an international comparison of real estate developers in Modderfontein Johannesburg and London's Royal Docks, Geoforum (2018), https://doi.org/10.1016/j.geoforum.2018.05.015

Brill, Frances. \& Reboredo, Ricardo. (2018). Failed Fantasies in a South African Context: the Case of Modderfontein, Johannesburg. Urban Forum https://doi.org/10.1007/s12132-018-9348-1

Brown, Roger, \& Young, Michael (2011). Coherent risk measures in real estate investment. Journal of Property Investment \& Finance, 29(4/5), 479-493. doi:10.1108/14635781111150358

Callon, Michel (1998). The laws of the markets : edited by Michel Callon. Oxford ; Malden, MA:

Oxford ; Blackwell Publishers/The Sociological Review.

Camden, L. B. o. (2004). Camden Unitary Development Plan.

Campbell, Heather, Tait, Malcom, \& Watkins, Craig. (2013). Is There Space for Better Planning in a Neoliberal World? Implications for Planning Practice and Theory. Journal of Planning Education and Research, 34(1), 45-59. doi:10.1177/0739456X13514614

Campkin, Ben (2013). Remaking London : decline and regeneration in urban culture London: London : I.B. Tauris.

Chan, Hei., Li, Shanjun, \& Zhang, Fan (2005). Firm competitiveness and the European Union emissions trading scheme. Energy Policy, 63, 1056.

Chen, Zhen, \& Khumpaisal, Sukulpat (2009). An analytic network process for risks assessment in commercial real estate development. Journal of Property Investment \& Finance, 27(3), 238-258. doi:10.1108/14635780910951957

Christophers, Brett (2014). Wild Dragons in the City: Urban Political Economy, Affordable Housing Development and the Performative World-making of Economic Models. International Journal of Urban and Regional Research, 38(1), 79-97. doi:10.1111/1468-2427.12037

Coiacetto, Eddo. (2001). Diversity in real estate developer behaviour: A case for research. Urban Policy and Research, 19(1), 43-59.

Coiacetto, Eddo, \& Bryant, Lyndall (2014). How Does Access to Development Finance Shape our Cities? Urban Policy and Research, 1-17. doi:10.1080/08111146.2014.924922

Colomb, Claire. (2007). Unpacking new labour's 'Urban Renaissance' agenda: Towards a socially sustainable reurbanization of British cities? Planning Practice \& Research, 22(1), 1-24. doi:10.1080/02697450701455249 
Corpataux, José., Crevoisier, Olivier., \& Theurillat, Thierry. (2009). The Expansion of the Finance Industry and Its Impact on the Economy: A Territorial Approach Based on Swiss Pension Funds. Economic Geography, 85(3), 313-334. doi:10.1111/j.1944-8287.2009.01035.x

Crosby, Neil, \& Henneberry, John (2016). Financialisation, the valuation of investment property and the urban built environment in the UK. Urban Studies, 53(7), 1424-1441. doi:10.1177/0042098015583229

David, Louise. (2012) 'The Social Construction of Real Estate Market Risk. The Case of a Financial Investments Cluster in Mexico City'. Articulo - Journal of Urban Research 9: 1-11.

David and Louise \& Halbert, Ludovic (2014) Financial capital, actor-network theory and the struggle over calculative agencies in the business property markets of Mexico City metropolitan region. Regional Studies 48 (3) :516-29. doi: 10.1080/00343404.2012.756581

Douglas, Mary \& Wildavsky, Aaron (1982). Risk and culture : an essay on the selection of technical and environmental dangers Berkeley ; London : University of California Press.

Edwards, Michael (1992). Microcosm: redevelopment proposals at King's Cross In A. Thornley (Ed.), The Crises of London. London: Routledge.

Edwards, Michael. (2009). King's Cross: renaissance for whom? In J. Punter (Ed.): Routledge.

Fainstein, Susan (2001). The city builders : property development in New York and London, 19802000 (2nd ed., rev. ed.). Lawrence: Lawrence : University Press of Kansas.

Fernandez, Rodrigo., Hofman, Annelore, \& Aalbers, Manuel. B. (2016). London and New York as a safe deposit box for the transnational wealth elite. Environment and Planning A, 48(12), 2443-2461. doi:10.1177/0308518X16659479

Fields, Desiree. (2018). Constructing a New Asset Class: Property- led Financial Accumulation after the Crisis. Economic Geography, 94(2), 118-140. doi:10.1080/00130095.2017.1397492

Fields, Desiree., \& Uffer, Sabina (2016). The financialization of rental housing: A comparative analysis of New York City and Berlin. Urban Studies, 53(7), 1486-1502. doi:10.1177/0042098014543704 Floricel, Serghei, \& Miller, R. (2001). Strategizing for anticipated risks and turbulence in large-scale engineering projects. International Journal of Project Management, 19(8), 445-455. doi:10.1016/S0263-7863(01)00047-3

Flux (2004) Statement of Community Engagement 1, 2, 3 prepared for Argent LLP

French, Nick, \& Gabrielli, Laura (2006). Uncertainty and feasibility studies: an Italian case study. Journal of Property Investment \& Finance, 24(1), 49-67. doi:10.1108/14635780610700732

Garrido, Marco (2013) The Ideology of the Dual City: The Modernist Ethic in the Corporate Development of Makati City, Metro Manila. International Journal of Urban and Regional Research 37(1): 165-85

Geva, Yinnon., \& Rosen, G. (2018). The regeneration deal: Developers, homeowners and new competencies in the development process. Geoforum, 96, 10-20.

Goodchild, Robin, \& Munton, Richard (1985). Development and the landowner : an analysis of the British experience. London: Allen \& Unwin.

Gotham, Kevin. Fox. (2006) The Secondary Circuit of Capital Reconsidered: Globalization and the U.S. Real Estate Sector. American Journal of Sociology 112 (1): 231-75. doi: 10.1086/502695

Gotham, Kevin. Fox. (2009). Creating Liquidity Out of Spatial Fixity: The Secondary Circuit of Capital and the Subprime Mortgage Crisis. International Journal of Urban and Regional Research 33 (2): 355-71. doi: 10.1111/j.1468-2427.2009.00874.x

Gotham, Kevin. Fox (2016). Coastal Restoration as Contested Terrain: Climate Change and the Political Economy of Risk Reduction in Louisiana. Sociological Forum. 31. 10.1111/socf.12273.

Graaskamp, James (1981) Fundamentals of Real Estate Development, Urban Land Institute, Washington D.C

Guironnet, Antoine \& Halbert, Ludovic. (2014) The Financialization of Urban Development Projects: Con- cepts, Processes, and Implications . Working Paper n¹4-04; décembre 2014; 44 pages. 2014. 
Guironnet, Antoine, Halbert, Ludovic, \& Attuyer, Katia. (2016). Building cities on financial assets: The financialization of property markets and its implications for city governments in the Paris cityregion. Urban Studies, 53(7), 1442-1464. doi:10.1177/0042098015576474

Guy, Simon \& Henneberry, John (2002). Development and developers : perspectives on property / Oxford ; Malden, MA Oxford: Oxford ; Malden, MA : Blackwell Science.

Haila, Anne (2016) Urban Land Rent: Singapore as a Property State. Chichester: Wiley

Halbert, Ludovic \& Attuyer, Katia (2016) Introduction: The financialisation of urban production: Conditions, mediations and transformations. Urban Studies. First published online on Feb. 26, 2016. doi:10.1177/0042098016635420A

Halbert, Ludovic., Attuyer, Katia, \& Guironnet, Antoine. (2016). Building cities on financial assets: The financialization of property markets and its implications for city governments in the Paris cityregion. Urban Studies, 53(7), 1442-1464. doi:10.1177/0042098015576474

Halbert, Ludvoic, \& Rouanet, Hortense. (2014). Filtering Risk Away: Global Finance Capital, Transcalar Territorial Networks and the (Un)Making of City-Regions: An Analysis of Business Property Development in Bangalore, India. Regional Studies, 48(3), 471-484. doi:10.1080/00343404.2013.779658

Healey, Patsy (1998). Collaborative Planning in a Stakeholder Society. The Town Planning Review, 69(1), 1-21. doi:10.3828/tpr.69.1.h651u2327m86326p

Henneberry, John, \& Parris, Simon (2013). The embedded developer: using project ecologies to analyse local property development networks. The Town Planning Review, 84(2), 227-249. doi:10.3828/tpr.2013.13

Holgersen, Ståle, \& Haarstad, Håvard (2009). Class, Community and Communicative Planning: Urban Redevelopment at King's Cross, London. Antipode, 41(2), 348-370. doi:10.1111/j.14678330.2009.00676.x

Huffman, Forrest (2003). Corporate real estate risk management and assessment. Journal of Corporate Real Estate, 5(1), 31-41. doi:10.1108/14630010310811984

Hyde, Zachary. (2018). "Giving Back to Get Ahead: Philanthropy as a Developer Strategy of Accumulation in Public-Private Social Housing," Geoforum

Kallman, James (2005). Managing Risk. Risk Management, 52(12), 46.

Kaperson, Jeanne, \& Kaperson, Roger. (2005). The social contours of risk: publics, risk communication and the social amplification of risk. Virginia Earthscan.

Kimelberg, Shelley (2011), Inside the Growth Machine: Real Estate Professionals on the Perceived Challenges of Urban Development. City \& Community, 10: 76-99. doi:10.1111/j.15406040.2010.01351.x

Leffers, Donald. (2017). Real estate developers' influence of land use legislation in the Toronto region: An institutionalist investigation of developers, land conflict and property law. Urban Studies, 0042098017736426. doi:10.1177/0042098017736426

Liu, Ze-Zhio., Zhu, Zheng-wei, Wang, Hui-jia, \& Huang, Jie. (2016). Handling social risks in government- driven mega project: An empirical case study from West China. International Journal of Project Management, 34(2), 202-218. doi:10.1016/j.ijproman.2015.11.003

Lupton, Debroah. (1999). Introduction: risk and sociocultural theory. Cambridge: Cambridge: Cambridge University Press.

Mairal, Gaspar. (2008). Narratives of risk. Journal of Risk Research, 11(1-2), 41-54. doi:10.1080/13669870701521321

Miller, Roger., \& Lessard, Donald (2007). Evolving Strategy: Risk Management and the Shaping of Large Engineering Projects. IDEAS Working Paper Series from RePEc.

Mosselson, Aidan (2017) 'Joburg has its own momentum': towards a vernacular theorisation of urban change. Urban Studies, 54, 1280-1296.

Parkes, Michael (2000). Maintaining the momentum through community activism in Kings Cross.

Local Economy: The Journal of the Local Economy Policy Unit, 15(3), 261-263.

doi:10.1080/02690940050174274 
Papin, Delphine. \& Newman, Peter (2010) De King's Cross à St Pancras, le nouveau quartier de l'Eurostar : géopolitique de 30 ans de conflits. Herodote: revue de geographie et de geopolitique.

Peck, Jamie \& Whiteside, Heather (2016) Financializing Detroit, Economic Geography, 92:3, 235268, DOI: $10.1080 / 00130095.2015 .1116369$

Penny, Joe (2017) Between coercion and consent: the politics of "Cooperative Governance" at a time of "Austerity Localism" in London, Urban Geography, 38:9, 1352-1373, DOI 10.1080/02723638.2016.1235932

Pike, Andy \& Pollard, Jane (2010), Economic Geographies of Financialization. Economic Geography, 86: 29-51. doi:10.1111/j.1944-8287.2009.01057.x

Raco, M., Street, E., \& Freire-Trigo, S. (2016). The new localism, anti-political development machines, and the role of planning consultants: Lessons from London's South Bank. Territory, Politics, Governance, 4(2), 216-240.

Rivero, Juan, Teresa, Benjamin, \& West, John. (2017). Locating rationalities in planning: market thinking and its others in the spaces, institutions, and materials of contemporary urban governance. Urban Geography, 38(2), 174-176. doi:10.1080/02723638.2016.1206703

Robin, Enora (2018) Performing real estate value(s): real estate developers, systems of expertise and the production of space Geoforum https://doi.org/10.1016/j.geoforum.2018.05.006

Rosen, Gillad. (2017). Toronto's condo- builders: development approaches and spatial preferences. Urban Geography, 38(4), 606-625. doi:10.1080/02723638.2016.1179426

Rutland, Ted. (2010), The Financialization of Urban Redevelopment. Geography Compass, 4: 11671178. doi:10.1111/j.1749-8198.2010.00348.x

Sanfelici, Daniel \& L. Halbert, Ludovic (2015) Financial markets, developers and housing in Brazil, Urban Studies. First published online on June 19, 2015. doi: 10.1177/0042098015590981.

Searle, Linda (2014). Conflict and Commensuration: Contested Market Making in India's Private Real Estate Development Sector. International Journal of Urban and Regional Research, 38(1), 60-78. doi:10.1111/1468-2427.12042

Shatkin, Gavin (2008). The City and the Bottom Line: Urban Megaprojects and the Privatization of Planning in Southeast Asia. Environment and Planning A, 40(2), 383-401. doi:10.1068/a38439

Smith, Neil (2002). New Globalism, New Urbanism: Gentrification as Global Urban Strategy. Antipode, 34(3), 427-450. doi:10.1111/1467-8330.00249

Teresa, Benjamin (2017). Rationalizing tax increment financing in Chicago. Urban Geography, 38(2), 199-220. doi:10.1080/02723638.2016.1206707

Theurillat, Thierry, and Olivier Crevoisier. (2013). 'The Sustainability of a Financialized Urban Megaproject: The Case of Sihlcity in Zurich'. International Journal of Urban and Regional Research 37 (6): 2052-2073.

Theurillat, T., Vera-Büchel, N., \& Crevoisier, O. (2016). Commentary: From capital landing to urban anchoring: The negotiated city. Urban Studies, 53(7), 1509-1518.

Urban Land Institute. ULI Case Studies. (2014) http://casestudies.uli.org/kings-cross

Vogelpohl, A. (2018). Consulting as a threat to local democracy? Flexible management consultants, Ward, Callum, and Erik Swyngedouw. 2018. 'Neoliberalisation from the Ground Up: Insurgent Capital, Regional Struggle and the Assetisation of Land'. Antipode 50 (4): 1077-97.

Weber, Rachel (2002). Do Better Contracts Make Better Economic Development Incentives? Journal of the American Planning Association, 68(1), 43-55. doi:10.1080/01944360208977190

Weber, Rachel (2010). Selling City Futures: The Financialization of Urban Redevelopment Policy. Economic Geography, 86(3), 251-274. doi:10.1111/j.1944-8287.2010.01077.x

Weber, Rachel (2015). From boom to bubble : how finance built the new Chicago: Chicago : The University of Chicago Press.

Weinstein, Liza (2014). 'One- Man Handled': Fragmented Power and Political Entrepreneurship in Globalizing Mumbai. International Journal of Urban and Regional Research, 38(1), 14-35. 
Weiss, Marc (1987). The rise of the community builders : the American real estate industry and urban land planning New York ; Guildford: New York ; Guildford : Columbia University Press. Winarso, Haryo \& Firman, Tommy. (2002). Residential land development in Jabotabek, Indonesia: Triggering economic crisis?. Habitat International. 26. 487-506. 10.1016/S0197-3975(02)00023-1. Zaloom, Caitlin (2003). Ambiguous numbers: trading technologies and interpretation in financial markets. American ethnologist, 30(2), 258-272. 